\title{
Tracing erosion rates in loess landscape of the Trzebnica Hills (Poland) over time using fallout and cosmogenic nuclides
}

\author{
Aleksandra Loba ${ }^{1}$ (1) $\cdot$ Jarosław Waroszewski ${ }^{1} \cdot$ Dmitry Tikhomirov $^{2} \cdot$ Fancesca Calitri $^{2,3} \cdot$ Marcus Christl $^{4}$. \\ Marcin Sykuła ${ }^{5}$ Markus Egli²
}

Received: 5 February 2021 / Accepted: 1 June 2021 / Published online: 16 June 2021

(c) The Author(s) 2021

\begin{abstract}
Purpose Loess landscapes are highly susceptible to soil erosion, which affects soil stability and productivity. Erosion is non-linear in time and space and determines whether soils form or degrade. While the spatial variability of erosion is often assessed by either modelling or on-site measurements, temporal trends over decades to millennia are very often lacking. In this study, we determined long- and short-term erosion rates to trace the dynamics of loess deposits in south-western Poland. Materials and methods We quantified long-term (millennial) erosion rates using cosmogenic (in situ ${ }^{10} \mathrm{Be}$ ) and short-term (decadal) rates with fallout radionuclides $\left({ }^{239+240} \mathrm{Pu}\right)$. Erosion processes were studied in two slope-soil transects (12 soil pits) with variable erosion features. As a reference site, an undisturbed soil profile under natural forest was sampled.

Results and discussion The long-term erosion rates ranged between 0.44 and $0.85 \mathrm{t} \mathrm{ha}^{-1}$ year $^{-1}$, whereas the short-term erosion rates varied from 1.2 to $10.9 \mathrm{t} \mathrm{ha}^{-1} \mathrm{year}^{-1}$ and seem to be reliable. The short-term erosion rates are up to 10 times higher than the long-term rates. The soil erosion rates are quite consistent with the terrain relief, with erosion increasing in the steeper slope sections and decreasing in the lower parts of the slope, while still maintaining high values.

Conclusions Soil erosion rates have increased during the last few decades owing to agriculture intensification and probably climate change. The measured values lie far above tolerable erosion rates, and the soils were found to be strongly imbalanced and exhibit a drastic shallowing of the productive soils horizons.
\end{abstract}

Keywords Soil erosion $\cdot$ In situ ${ }^{10} \mathrm{Be} \cdot{ }^{239+240} \mathrm{Pu} \cdot$ Loess landscape $\cdot$ Radionuclides

\section{Introduction}

Responsible editor: Pariente Sarah

Aleksandra Loba

aleksandra.loba@upwr.edu.pl

1 Institute of Soil Science and Environmental Protection, Wroclaw University of Environmental and Life Sciences, Grunwaldzka 53, 50-357 Wroclaw, Poland

2 Department of Geography, University of Zurich, 8057 Zurich, Switzerland

3 Leibniz-Centre for Agricultural Landscape Research (ZALF), Eberswalder Straße 84, 15374 Muncheberg, Germany

4 Laboratory of Ion Beam Physics, ETH-Zurich, 8093 Zurich, Switzerland

5 Department of Soil Science and Landscape Management, Nicolaus Copernicus University in Toruń, Lwowska Str. 1, 87-100 Torun, Poland
The increase in soil erosion is a direct consequence of agricultural exploitation and threatens soil stability, quality and its productivity (Rickson 2014; Guzmán et al. 2015; Alewell et al. 2017; Golosov et al. 2021). Long-term and intense erosion removes topsoil from the upper part of a slope and deposits the eroded material at the toe of the slope, thus leading to irreversible changes in the natural structure of those soils and their corresponding horizons (Świtoniak et al. 2016; Zádorová and Penížek 2018; Golosov et al. 2021). One of the materials most susceptible to erosion are loess deposits (Licznar et al. 1981; Yang et al. 2006; Zhang et al. 2018; Poręba et al. 2019). Loess materials are widely distributed across the world (Muhs 2013; Schaetzl and Attig 2013; Pasquini et al. 2017). In Europe, the most extensive deposits on Earth cover an area from France to Russia, having developed during the Last Glacial period (Haase et al. 2007; Lehmkuhl et al. 2020). Productive soils have 
developed on the loess, including Chernozems, Pheozems and Luvisols (Altermann et al. 2005; Gerlach et al. 2012; Labaz et al. 2018; Kabała et al. 2019; Loba et al. 2020). As a consequence, since the Neolithic period, loess areas have been deforested and transformed into arable lands, which has given rise to intense soil erosion processes (Altermann et al. 2005; Gerlach et al. 2012; Poręba et al. 2019).

So far, ${ }^{137} \mathrm{Cs}$ has predominantly been used as the isotope tracer for soil erosion in loess landscapes (Yang et al. 2006; Poręba et al. 2011, 2015, 2019). ${ }^{137} \mathrm{Cs}$ is a fallout radionuclide (FRN) that is distributed globally as a result of, for example, nuclear weapons testing in the 1960s and nuclear power plant accidents, and so it enables the investigation of erosion rates over the last few decades (Alewell et al. 2014, 2017; Zollinger et al. 2015; Meusburger et al. 2016). However, it is characterised by a short half-life of 30.17 year, and recent estimations have indicated that more than $70 \%$ of the global ${ }^{137} \mathrm{Cs}$ has disappeared due to its radioactive decay (Xu et al. 2015). At sites exhibiting erosion and a subsequent additional loss of ${ }^{137} \mathrm{Cs}$, its detectability becomes increasingly difficult. Moreover, the Chernobyl accident in 1986 caused a spatially inhomogeneous distribution of ${ }^{137} \mathrm{Cs}$ in Central and Western Europe, which has caused some limitations in its application (Arata et al. 2016a; Alewell et al. 2017). As a result, ${ }^{239+240} \mathrm{Pu}$ isotopes are currently more often used due to their longer half-lives $(24,110$ and 6561 years, respectively) and because $\mathrm{Pu}$ is absent from the volatile fraction released by the reactor accident of Chernobyl (Arata et al. 2016a).

Long-term erosion rates (over several millennia) can be determined using cosmogenic nuclides, such as ${ }^{10} \mathrm{Be}$ (Hidy et al. 2010; Zollinger et al. 2015; Calitri et al. 2019). Based on their origin, two types of ${ }^{10} \mathrm{Be}$ are distinguished: (1) meteoric ${ }^{10} \mathrm{Be}$, which is constantly produced in the upper atmosphere by the spallation of nitrogen and oxygen by cosmic rays and is deposited at the Earth's surface by rainfall (Graly et al. 2010; Willenbring and von Blanckenburg 2010; Wyshnytzky et al. 2015), and (2) in situ ${ }^{10} \mathrm{Be}$, which is directly produced in the crystal lattice of quartz by the interaction of cosmogenic rays (Hidy et al. 2010). For loess landscapes, there is a lack of studies using meteoric or in situ ${ }^{10} \mathrm{Be}$ to determine denudation rates. Meteoric ${ }^{10} \mathrm{Be}$ has been applied to studying palaeoclimatic variations (Gu et al. 1997; Zhou et al. 2015), estimating palaeoprecipitation (Sartori et al. 2005), establishing time scales for loess deposition (Chengde et al. 1992) and in tracking the translocation of ${ }^{10} \mathrm{Be}$ in Luvisols (Jagercikova et al. 2015). In most cases, ${ }^{10} \mathrm{Be}$ and ${ }^{239+240} \mathrm{Pu}$ or ${ }^{137} \mathrm{Cs}$ have been used separately for calculating erosion rates (Arata et al. 2016a; Waroszewski et al. 2018; Musso et al. 2020). Recent studies, however, have combined these two types of isotopes to compare medium- and long-term erosion rates.
For instance, Zollinger et al. (2015), Calitri et al. (2019) and Jelinski et al. (2019) applied both types of isotopes to compare erosion processes for the last 50-60 years with long-term rates in order to crystallise the effects of anthropogenic pressures and climate change on soil processes.

In this study, we made a first attempt to apply in situ ${ }^{10} \mathrm{Be}$ and ${ }^{239+240} \mathrm{Pu}$ to quantify soil erosion in a loess landscape, with special focus on (1) documenting long- and short-term erosion rates, (2) cross-checking recent and past erosion rates to determine how much erosive processes have intensified in recent decades and (3) verifying whether isotopic methods are suitable tools for studying erosion processes in the south-western Polish loess belt.

\section{Study area}

The investigation area was located in the Trzebnica Hills, south-western Poland (Fig. 1). The subglacial glaciotectonic disturbances in this region are estimated to have come from the Odra Glaciation (Saalian-Drenthe, marine isotope stage [MIS] 8/6) (Krzyszkowski 1993; Jary 1996). In general, the local geology is dominated by Quaternary deposits (loess, glacial till, fluvioglacial sediments), but Neogene deposits (clays, sands and gravels) occur locally in small areas (Pachucki 1952; Dyjor 1970; Dyjor and Kościówko 1982; Jary 1996). Loess, which is the youngest deposit, is distributed across the Trzebnica Hills as a layer with varying thickness (Jary 1996). The outcrop in Zaprężyn provides a record of loess dynamics and pedogenesis from the Last Interglacial (Eemian, MIS 5e) to the Upper Pleniweichselian (MIS2) (Jary and Ciszek 2013).

The soils in this region, mostly developed from the loess deposits, are characterised by subsoil clay illuviation (Luvisols) or the presence of a dark humic topsoil (Chernozems and Pheozems) (Licznar et al. 1988; Licznar and Licznar 2002; Zmuda et al. 2009; Kabała and Marzec 2010; Glina et al. 2014) and have been affected by denudation processes due to agricultural use since the Neolithic period (Poręba et al. 2011).

The native vegetation is represented by oak-hornbeam forest, although most of the land is used for agriculture due to the productivity of the soils (Aniol-Kwiatkowska 1998). The main crops cultivated are wheat, beetroot and corn. According to the Köppen-Geiger climate classification, the Trzebnica Hills experience warm summers and a humid, continental climate. The mean annual temperature is $8{ }^{\circ} \mathrm{C}$, with average temperatures in the coldest and warmest months being $-3{ }^{\circ} \mathrm{C}$ (January) and $17^{\circ} \mathrm{C}$ (July), respectively (Bac and Rojek 2012). The annual average precipitation is ca. $600 \mathrm{~mm}$ (Bac and Rojek 2012). 
Fig. 1 Map of the study sites in the Trzebnica Hills

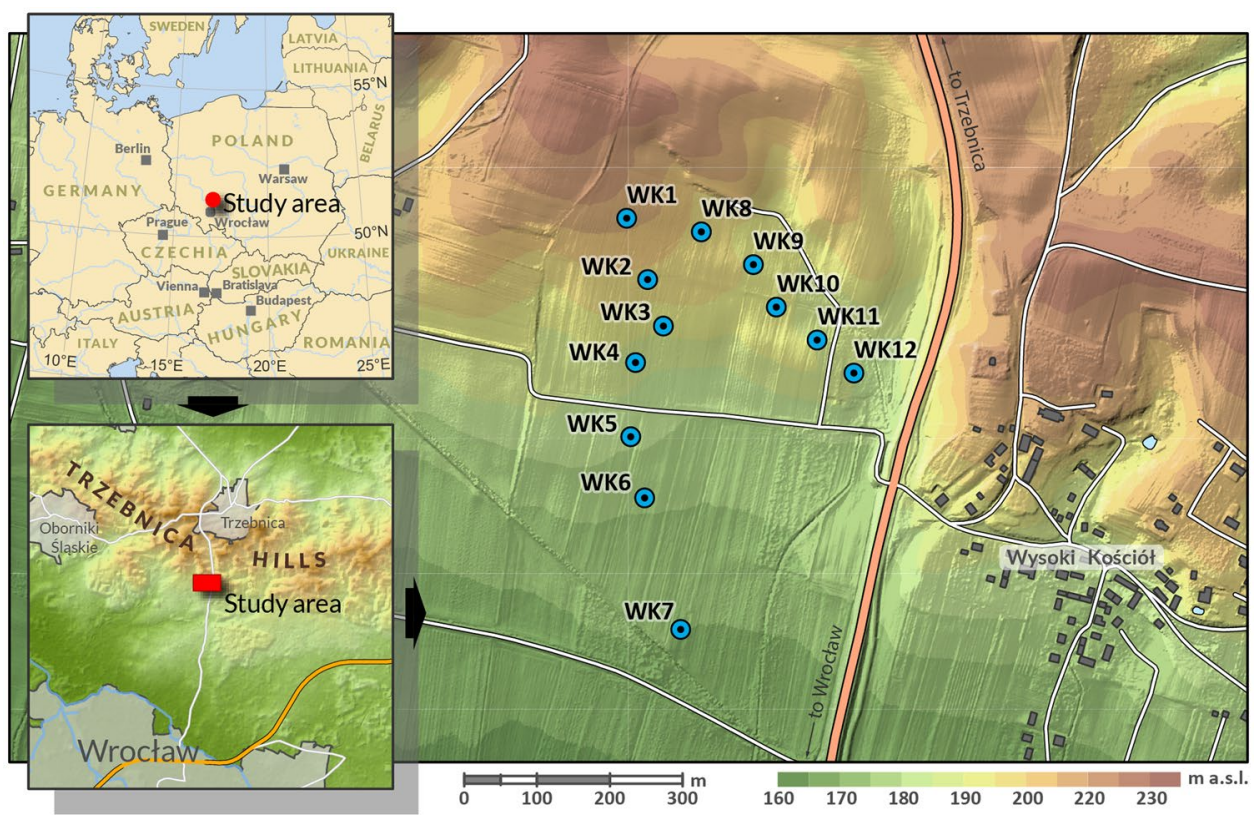

\section{Materials and methods}

\subsection{Field sampling}

The sites sampled were in the southern part of the Trzebnica Hills, close to the village of Wysoki Kościót. Two transects along two slopes with pronounced erosion features were samples in order to track the multidirectional character of soil erosion (Table 1, Fig. 1). The two slope catenas started at the top of the local hill, sharing sample WK1 as the starting profile for both transects, and with the first transect (WK1, WK2-WK7) trending to the south and the second (WK1, WK8-WK12) to the north-east. The range of slope inclination was similar for both transects and reached the highest values with $12-13^{\circ}$ at the shoulder position (Table 1). The altitudinal differences along the first catena (WK1-WK7) are about $36 \mathrm{~m}$ and along the second catena (WK1-WK12) $20 \mathrm{~m}$. For each transect, the soil profiles were described according to the guidelines for soil description (Food and Agriculture Organization [FAO] 2006) and classified according to the FAO-World Reference Base (WRB) system (International Union of Soil Sciences Working Group WRB 2015). Undisturbed soil samples were taken, using stainless steel rings $\left(100 \mathrm{~cm}^{3}\right)$, from all the soil horizons for bulk density analysis. About $1 \mathrm{~kg}$ of bulk soil material was sampled for physicochemical and geochemical analyses. To obtain enough quartz $(0.25-0.60 \mathrm{~mm}$ fraction) for in situ ${ }^{10} \mathrm{Be}$ analysis, $8-9 \mathrm{~kg}$ of soil material were taken at depths of $20 \mathrm{~cm}$ from the surface to $100 \mathrm{~cm}$. For the ${ }^{239+240} \mathrm{Pu}$ analyses, samples were taken every $5 \mathrm{~cm}$ from the surface to a depth of $40 \mathrm{~cm}$. However, the Ap horizon (0-20/0-25 cm) was mostly homogenous due to ploughing, so only one sample was taken from the first $20 / 25 \mathrm{~cm}$. In addition, a reference soil profile was sampled in a nearby forested area. To overcome the large sampling number, a large amount of sample material (about $1 \mathrm{~kg}$ ) was taken per depth increment and homogenised. Prior to the measurements, the soil samples were dried, crushed and sieved ( $2 \mathrm{~mm}$ mesh).

\subsection{Soil properties}

The particle-size distribution was measured using a sieving (sand fraction) and hydrometer method to determine the silt and clay fractions (van Reeuwijk 2002). The $\mathrm{pH}$ of the samples was measured potentiometrically (in deionised water) in a 1:2.5 suspension (Kabała et al. 2016). The hydrolytic acidity was extracted using a 1-M sodium acetate $\left(\mathrm{CH}_{3} \mathrm{COONa}\right)$ solution and potentiometric titration, while the exchangeable ions $\left(\mathrm{Ca}^{2+}, \mathrm{Mg}^{2+}, \mathrm{K}^{+}, \mathrm{Na}^{+}\right)$were extracted using a 1-M ammonium acetate $\left(\mathrm{CH}_{3} \mathrm{COONH}_{4}\right)$ solution at pH 7(van Reeuwijk 2002). Calcium carbonate $\left(\mathrm{CaCO}_{3}\right)$ was measured conductometrically using a Scheibler apparatus. The soil organic carbon (SOC) content was determined by dry combustion at $550{ }^{\circ} \mathrm{C}$ and the non-dispersive infrared absorption of $\mathrm{CO}_{2}$, using a Ströhlein CS-mat 5500 analyser (prior to the analysis, the calcium carbonates were removed, if present). The bulk density was measured using the dry weight method (van Reeuwijk 2002).

The geochemical composition was determined using $\mathrm{X}$-ray fluorescence (XRF). Approximately $5 \mathrm{~g}$ of soil was milled to $50 \mu \mathrm{m}$ in a tungsten carbide disc swing mill (Retsch ${ }^{\circledR}$ RS1, Germany). The milled samples were then weighed into plastic cups using a Prolen ${ }^{\circledR}$ foil and measured using an energy-dispersive, helium-flushed XRF 
Table 1 Main characteristics of studied sites

\begin{tabular}{|c|c|c|c|c|c|c|}
\hline Soil profile & Latitude and longitude & $\begin{array}{l}\text { Elevation } \\
\text { (m asl) }\end{array}$ & $\begin{array}{l}\text { Inclination } \\
\left({ }^{\circ}\right)\end{array}$ & Slope position & Land use & Classification according to WRB (IUSS, 2015) \\
\hline WK1 & $\begin{array}{l}51^{\circ} 16^{\prime} 09.0^{\prime \prime} \mathrm{N} \\
17^{\circ} 02^{\prime} 36.7^{\prime \prime} \mathrm{E}\end{array}$ & 206.8 & 4 & Top slope & Arable land & Albic Luvisol (Aric, Cutanic, Densic, Ochric, Siltic) \\
\hline WK2 & $\begin{array}{l}51^{\circ} 16^{\prime} 06.3^{\prime \prime} \mathrm{N} \\
17^{\circ} 02^{\prime} 38.3^{\prime \prime} \mathrm{E}\end{array}$ & 198.2 & 10 & Shoulder & Arable land & $\begin{array}{l}\text { Haplic Luvisol (Aric, Cutanic, Endodensic, } \\
\text { Endoloamic, Ochric, Episiltic, Raptic) }\end{array}$ \\
\hline WK3 & $\begin{array}{l}51^{\circ} 16^{\prime} 02.6^{\prime \prime} \mathrm{N} \\
17^{\circ} 02^{\prime} 37.6^{\prime \prime} \mathrm{E}\end{array}$ & 191.8 & 13 & Shoulder & Arable land & Lamellic Luvisol (Aric, Cutanic, Ochric, Siltic) \\
\hline WK4 & $\begin{array}{l}51^{\circ} 15^{\prime} 59.3^{\prime \prime} \mathrm{N} \\
17^{\circ} 02^{\prime} 37.4^{\prime \prime} \mathrm{E}\end{array}$ & 187.1 & 10 & Back slope & Arable land & Stagnic Albic Luvisol (Aric, Cutanic, Ochric, Siltic) \\
\hline WK5 & $\begin{array}{l}51^{\circ} 15^{\prime} 56.6^{\prime \prime} \mathrm{N} \\
17^{\circ} 02^{\prime} 38.5^{\prime \prime} \mathrm{E}\end{array}$ & 181.1 & 5 & Back slope & Arable land & Albic Luvisol (Aric, Cutanic, Ochric, Siltic) \\
\hline WK6 & $\begin{array}{l}51^{\circ} 15^{\prime} 50.8^{\prime \prime} \mathrm{N} \\
17^{\circ} 02^{\prime} 41.3^{\prime \prime} \mathrm{E}\end{array}$ & 176.1 & 3 & Foot slope & Arable land & $\begin{array}{l}\text { Haplic Luvisol (Aric, Colluvic, Cutanic, } \\
\text { Endoloamic, Ochric, Episiltic) }\end{array}$ \\
\hline WK7 & $\begin{array}{l}51^{\circ} 16^{\prime} 04.3^{\prime \prime} \mathrm{N} \\
17^{\circ} 02^{\prime} 39.5^{\prime \prime} \mathrm{E}\end{array}$ & 170.2 & 2 & Toe slope & Arable land & $\begin{array}{l}\text { Eutric Colluvic Regosol (Aric, Ochric, Raptic, } \\
\text { Episiltic) }\end{array}$ \\
\hline WK8 & $\begin{array}{l}51^{\circ} 16^{\prime} 08.5^{\prime \prime} \mathrm{N} \\
17^{\circ} 02^{\prime} 42.0^{\prime \prime} \mathrm{E}\end{array}$ & 198.1 & 7 & Shoulder & Arable land & $\begin{array}{l}\text { Calcic Luvisol (Aric, Cutanic, Densic, Endoloamic, } \\
\text { Ochric, Episiltic, Raptic) }\end{array}$ \\
\hline WK9 & $\begin{array}{l}51^{\circ} 16^{\prime} 07.1^{\prime \prime} \mathrm{N} \\
17^{\circ} 02^{\prime} 45.8^{\prime \prime} \mathrm{E}\end{array}$ & 193.7 & 12 & Shoulder & Arable land & $\begin{array}{l}\text { Regosol (Aric, Densic, Endoloamic, Ochric, } \\
\text { Episiltic) }\end{array}$ \\
\hline WK10 & $\begin{array}{l}51^{\circ} 16^{\prime} 05.2^{\prime \prime} \mathrm{N} \\
17^{\circ} 02^{\prime} 47.5^{\prime \prime} \mathrm{E}\end{array}$ & 191.4 & 7 & Back slope & Arable land & $\begin{array}{l}\text { Haplic Luvisol (Aric, Cutanic, Endoloamic, Ochric, } \\
\text { Episiltic, Raptic) }\end{array}$ \\
\hline WK11 & $\begin{array}{l}51^{\circ} 16^{\prime} 03.8^{\prime \prime} \mathrm{N} \\
17^{\circ} 02^{\prime} 50.4^{\prime \prime} \mathrm{E}\end{array}$ & 188.9 & 3 & Back slope & Arable land & Haplic Luvisol (Aric, Cutanic, Ochric, Siltic) \\
\hline WK12 & $\begin{array}{l}51^{\circ} 16^{\prime} 02.4^{\prime \prime} \mathrm{N} \\
17^{\circ} 02^{\prime} 53.1^{\prime \prime} \mathrm{E}\end{array}$ & 185.6 & 2 & Foot slope & Arable land & Endostagnic Luvisol (Colluvic, Ochric, Siltic) \\
\hline WKo* & $\begin{array}{l}51^{\circ} 16^{\prime} 49.28^{\prime \prime} \\
17^{\circ} 04^{\prime} 15.01^{\prime \prime}\end{array}$ & 225.9 & 0 & Plateau & Forest & Albic Luvisol (Ochric, Siltic) \\
\hline
\end{tabular}

*Reference profile

spectrometer (ED-XRF, SPECTRO X-LAB 2000). The accuracy of the measurements was checked using soil reference material (Reference Soil Sample CCRMP SO-4, Canada Centre for Mineral and Energy Technology) with certified total element contents.

To estimate the degree of weathering of the soil layers, the Chemical Index of Alternation (CIA) (Nesbitt and Young 1982) was used (molar ratios):

$\mathrm{CIA} \times\left[\frac{\mathrm{A1}_{0} \mathrm{O}_{3}}{\mathrm{A1}_{0} \mathrm{O}_{3}+\mathrm{CaO}+\mathrm{Na}_{2} \mathrm{O}+\mathrm{K}_{2} \mathrm{O}}\right]$

\subsection{Determination of cosmogenic, in situ ${ }^{10} \mathrm{Be}$}

${ }^{10} \mathrm{Be}$ was extracted from pre-cleaned quartz grains from the $0.25-0.60 \mathrm{~mm}$ fraction using an isotope dilution method that followed the modified protocol of von Blanckenburg (Kohl and Nishiizumi 1992; von Blanckenburg et al. 1996) at the University of Zurich. The ${ }^{10} \mathrm{Be} /{ }^{9} \mathrm{Be}$ ratios were measured using a Tandy accelerator mass spectrometer (AMS) at ETH Zurich (Christl et al. 2013), normalised to the ETH AMS standard S2007 N $\left({ }^{10} \mathrm{Be} /{ }^{9} \mathrm{Be}=28.1 \times 10^{-12}\right.$ nominal $)$ and calibrated to ICN $01-5-1\left({ }^{10} \mathrm{Be} /{ }^{9} \mathrm{Be}=2.709\right.$ $\times 10^{-11}$ nominal) (Nishiizumi et al. 2007), both associated with a ${ }^{10} \mathrm{Be}$ half-life of $1.387 \pm 0.012 \mathrm{Myr}$.

\subsection{Determination of the ${ }^{239+240} \mathrm{Pu}$ activity in soils}

The soil samples were prepared and measured for plutonium isotope analysis according to the method of Ketterer et al. (2004). Concentrations of ${ }^{239} \mathrm{Pu}$ and ${ }^{240} \mathrm{Pu}$ were measured relative to the ${ }^{242} \mathrm{Pu}$ spike using an Agilent 8800 Triple quad ICP-MS spectrometer equipped with an ICA Apex-IR nebuliser, which allows the detection of ultra-trace-elemental concentrations down to the parts-per-quadrillion level. The resulting concentrations were converted into the combined activity of ${ }^{239+240} \mathrm{Pu}$, corrected to the preparation blanks and normalised to the standard reference material IAEA-447 (IAEACU-2009-03 2012). The reproducibility of the laboratory preparation was checked using randomly-picked duplicates of the samples. 


\subsection{Calculation of soil redistribution rates}

The long-term erosion rate was determined based on the assumption of the secular equilibrium of ${ }^{10} \mathrm{Be}$ production and decay in the upper $80 \mathrm{~cm}$ of the soil. We used the CRONUS online calculator to convert ${ }^{10} \mathrm{Be}$ concentrations into an erosion rate (Balco et al. 2008; https://hess.ess. washington.edu). The calculator includes all production channels of ${ }^{10} \mathrm{Be}$ by secondary cosmic rays through the specified soil depth. For the short-term denudation rates, two conversion models were applied:

1. The profile distribution model (PDM) of Walling and Quine (1990) and Zhang et al. (1990), which was developed to convert FRN inventories into soil redistribution rates for undisturbed sites. A recent study by Calitri et al. (2019), however, showed that it can also be used for agricultural soils:

$\mathrm{E}=\frac{10}{\mathrm{t}-\mathrm{t}_{0}} \times \ln \left(1-\frac{\mathrm{X}}{100}\right) \times \mathrm{h}_{0}$

where $\mathrm{E}$ is the erosion rate $\left(\mathrm{t} \mathrm{ha}^{-1}\right.$ year $\left.^{-1}\right), \mathrm{t}$ is the year of sampling, $\mathrm{t}_{0}$ is 1963 (year of thermonuclear weapons testing), $\mathrm{X}$ is the $\%$ reduction in total inventory with regard to the local reference value and $\mathrm{h}_{0}$ is a profile shape factor; and.

2. Modelling Deposition and Erosion rates with RadioNuclides (MODERN) (Arata et al. 2016a, b), which models the FRN depth profile using a stepwise function. For each increment, inc returns a value Inv $v_{i n c}$, which is the total inventory of the sampling site, measured for the whole depth profile, $\mathrm{d}(\mathrm{cm})$. MODERN provides results in centimetres $(\mathrm{cm})$ of soil loss or gain and can be calculated in $\mathrm{tha}^{-1} \mathrm{year}^{-1}$ using the equation:

$$
\mathrm{Y}=10 \times \frac{\mathrm{x}^{*} \mathrm{xm}}{\mathrm{d} \cdot \mathrm{t}_{1}-\mathrm{t}_{0}}
$$

where $\mathrm{Y}$ is the soil erosion or deposition rate $(\mathrm{t}$ $\mathrm{ha}^{-1}$ year $\left.^{-1}\right), \mathrm{x}^{*}$ is the soil loss or gain returned in centimetres from MODERN, $\mathrm{xm}$ is the mass depth $\left(\mathrm{kg} \mathrm{m}^{-2}\right)$, $\mathrm{d}$ is the total depth increment considered at the sampling site, $t_{1}$ is the sampling year and $t_{0}$ is the reference year.

\subsection{Statistical analysis}

To test the statistical association between the chosen soils and relief characteristics, the Pearson's correlation coefficients were calculated using Statistica 13 software.

\section{Results}

\subsection{Morphology and soil properties}

The soils along the two studied transects predominantly developed from loess deposits that had a thickness of up to $1.5 \mathrm{~m}$ (Table 2). In some cases, the thin loess mantle (shallowed by erosion) was found to be underlain by a glaciofluvial substrate (WK2) and/or a calcareous glacial till (WK7, WK8, WK9). These lithic discontinuities were clearly recognisable in the grain size distribution and in part in the bulk density (Table 2). The loess deposits had a silt loam texture with a dominance of coarse silt, while the glaciofluvial and glacial sediments had a sandy loam, loam or clay loam texture. In general, the loess mantle was completely decalcified along the first transect (except for the glacial till in WK7), while the profiles WK8 and WK9 of the second transect contained some small amounts of calcium carbonate $(0.02-5.80 \%)$. As a result, the presence of calcium carbonate is linked to a high base saturation and relatively high $\mathrm{pH}$ (Table 2). All soils were characterised by a low SOC content, oscillating between 0.09 and $0.88 \%$, and by a very low nitrogen content $(0.02-0.08 \%)$.f

Almost all the soils revealed a clear morphological differentiation related to clay illuviation. Complete Luvisols, with E and Bt horizons, were only found at the top of the studied hill (WK1) and in the mid-slope section (WK4-WK6), however. The other soil profiles had strong features related to erosion, such as the absence of an E horizon and the incorporation of the Bt into the Ap horizon (WK2, WK3, WK10, WK11), or the deposition of eroded fine-grained material covering the remnants of an older A horizon (WK6; Ab horizon at a depth of $45 \mathrm{~cm}$ ) and the formation of a thick colluvium (nearly $60 \mathrm{~cm}$ in depth) in the toe slope (WK12). In profile WK7, a clear stratification of sand and silt was detected over the glacial till. The sandy material revealed a diagonal lineation. The morphology of the soils suggests a strong differentiation caused by significant geomophodynamic processes acting on the slopes. This led to the shallowing of the loess deposits and exhumation of glaciofluvial and glacial sediments.

\subsection{Geochemical composition of the soils}

The content of major oxides in the soils was relatively similar in both transects (Table $\mathrm{S} 1$ ), oscillating in the range of $61.1-87.0 \%$ for $\mathrm{SiO}_{2}, 5.6-11.8 \%$ for $\mathrm{Al}_{2} \mathrm{O}_{3}, 1.0-3.7 \%$ for $\mathrm{Fe}_{2} \mathrm{O}_{3}$ and $1.7-2.8 \%$ for $\mathrm{K}_{2} \mathrm{O}$. The $\mathrm{CaO}$ content mainly ranged from 0.4 to $0.7 \%$, whereas the Ca content was significantly higher in horizons bearing carbonate nodules. 


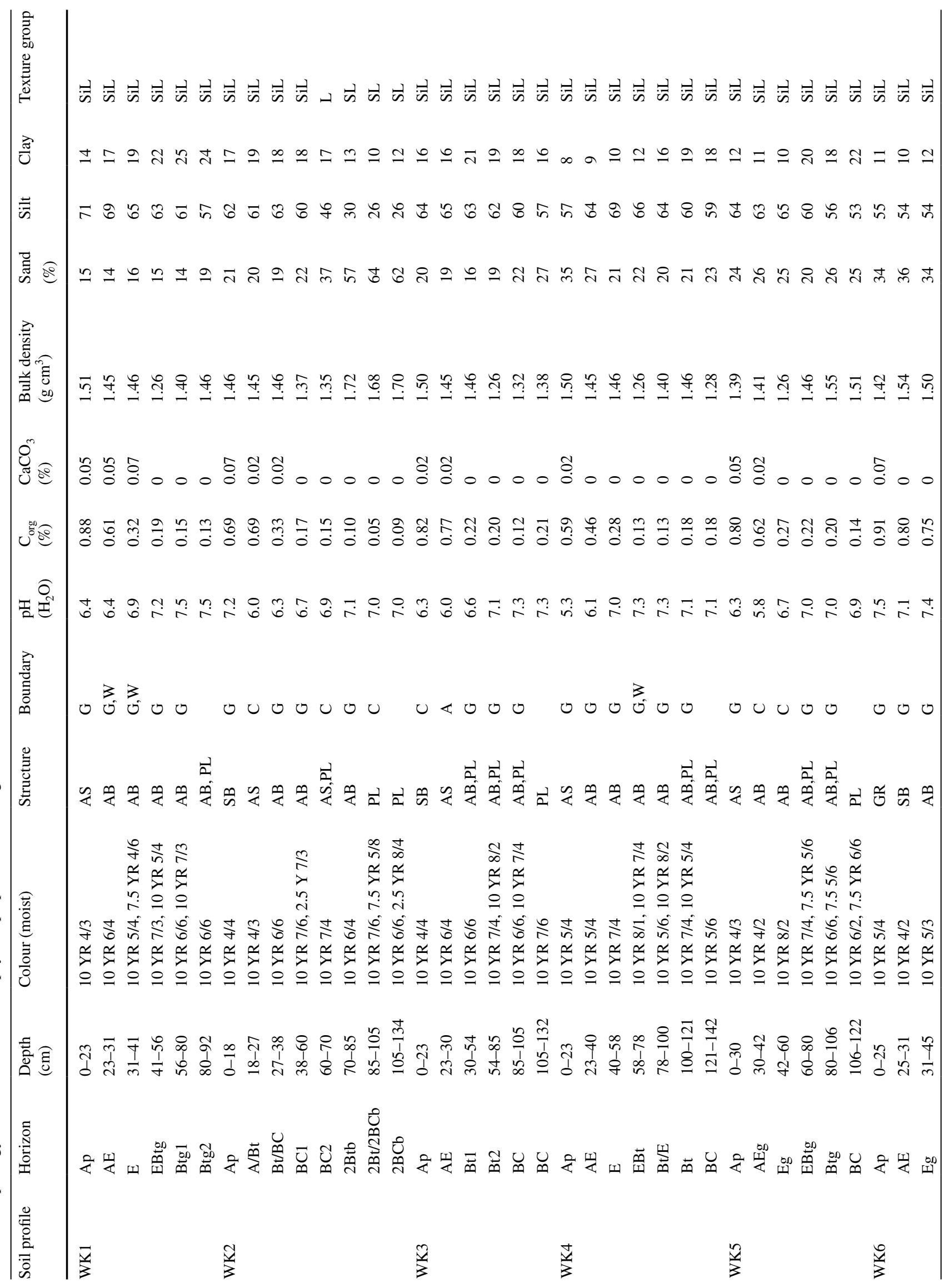




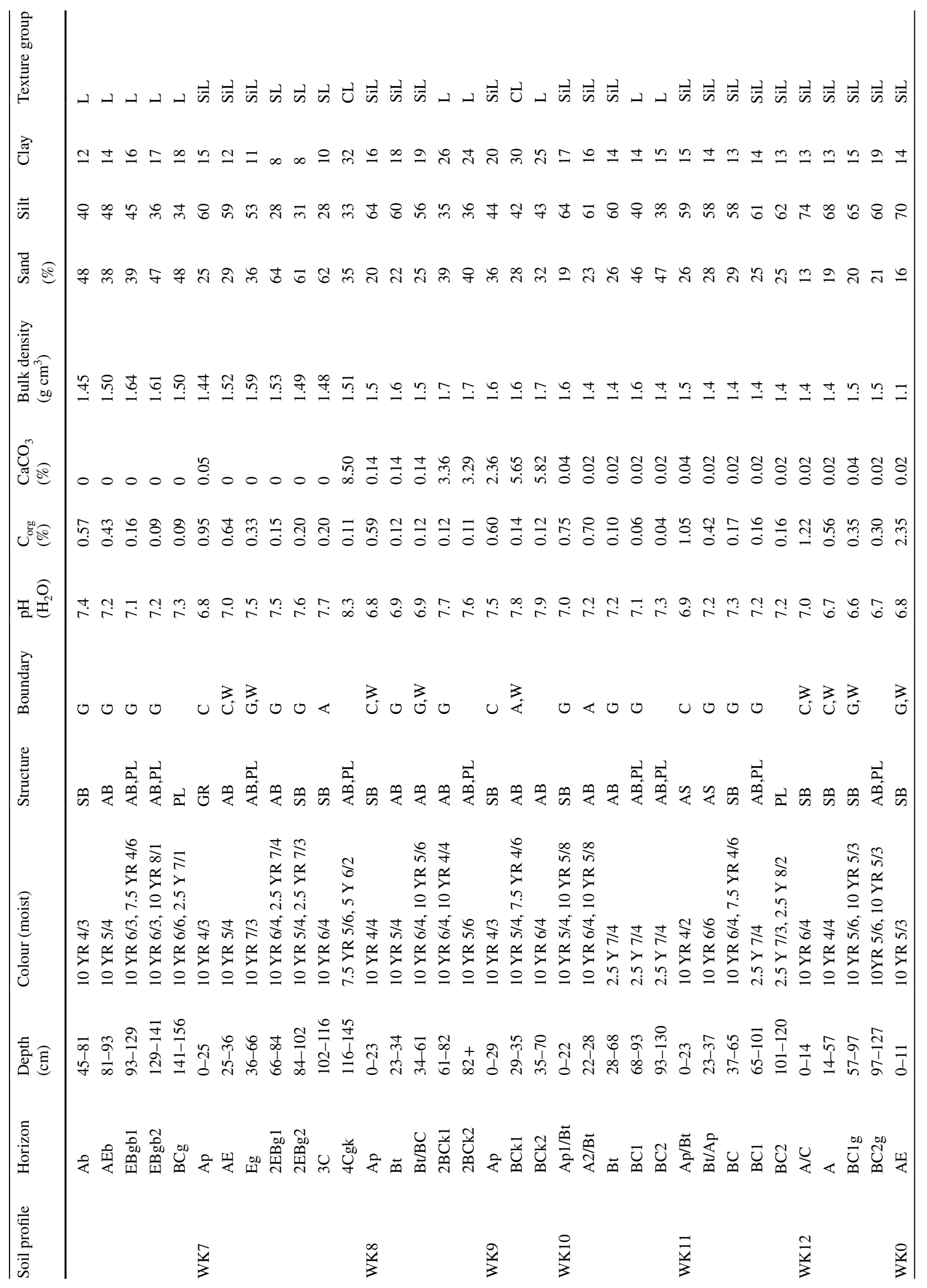


The $\mathrm{Zr}$ and $\mathrm{Hf}$ content often indicates the presence of aeolian material (De Vos and Tarvainen 2006), and they were used to discriminate these from glacial sediments. The average $\mathrm{Zr}$ and $\mathrm{Hf}$ contents in the loess layer were 302 and $8.9 \mathrm{mg} \mathrm{kg}^{-1}$, respectively (McLennan 2001). The lowermost horizons of WK2, WK7, WK8 and WK9 had lower $\mathrm{Zr}$ and $\mathrm{Hf}$ contents, with a maximum of 256 and $6.9 \mathrm{mg} \mathrm{kg}^{-1}$, respectively. This reflects the lithological discontinuity observed in the field. The relatively high variability of $\mathrm{Hf}$ and $\mathrm{Zr}$ in soil profiles WK5 and WK6 highlights the dynamics of slope processes and/or loess sorting along the slope (Table S1). The reference soil profile (WK0) situated in the forested area was characterised by similar values for the major oxides, $\mathrm{Zr}$ and $\mathrm{Hf}$ as in the studied soils, which confirm their origin as loess deposits.

The majority of the soils revealed CIA values above 50 (Table S1), corresponding to a low degree of weathering. Only the samples from profiles WK8 and WK9 and the lowermost horizon of WK7 had CIA value of below 50, representing less-weathered material (Nesbitt and Young 1982).

\subsection{In situ ${ }^{10} \mathrm{Be}$ and erosion rates}

The average content of in situ ${ }^{10} \mathrm{Be}$ in the soils ranged from 0.9 to $1.5\left(\times 10^{5}\right)$ atoms $\mathrm{g}^{-1}$ (Table 3 ). In both transects, the soils situated on the upper part of the slope had slightly lower concentrations than the soils in lower/toe slope positions. The calculated long-term erosion rates were similar for both transects. In profile WK1 (the starting point for both transects), the long-term erosion rate was $0.46 \mathrm{t} \mathrm{ha}^{-1}$ year $^{-1}$. In the mid-slope position, the erosion rate increased, oscillating between 0.56 and $0.85 \mathrm{tha}^{-1}$ year $^{-1}$, while in the toe slope, it decreased again down to $0.44-0.50 \mathrm{t} \mathrm{ha}^{-1}$ year $^{-1}$. The site with the highest erosion rate was WK9, with the lowest erosion rate measured in WK6 (Fig. 2).

\subsection{Activity of ${ }^{239+240} \mathrm{Pu}$ and erosion rates}

The plutonium activity in the soils was generally low, ranging from 0.002 to $0.520 \mathrm{~Bq} \mathrm{~kg}^{-1}$ (Table 4, Fig. 3). The isotopic ratio of ${ }^{240} \mathrm{Pu} /{ }^{239} \mathrm{Pu}$ (Table 4) can be used to determine the origin of the plutonium in soils (Alewell et al. 2014, 2017). The ratio refers to Northern Hemisphere mid-latitude weapons testing fallout (Alewell et al. 2017) when its value ranges between 0.14 and 24 (typically around 0.18 ), whereas ratios of 0.37 to 0.41 indicate influence from the Chernobyl accident (Alewell et al. 2017). The mean ratio of ${ }^{240} \mathrm{Pu} /{ }^{239} \mathrm{Pu}$ in the investigated soils was 0.18 , indicating no influence from the Chernobyl fallout. The erosion rates varied considerably depending on the model applied (Fig. 2, Table S2). The PDM gave higher erosion rates, ranging from 1.4 to $16.9 \mathrm{t} \mathrm{ha}^{-1}$ year $^{-1}$, whereas MODERN gave lower rates of between 1.2 and $10.9 \mathrm{t} \mathrm{ha}^{-1}$ year $^{-1}$. In general, the soils of the second transect experienced higher erosion rates 
Table 3 Content of in situ ${ }^{10} \mathrm{Be}$ in the soil samples

\begin{tabular}{lllll}
\hline Soil profile & ${ }^{10} \mathrm{Be} /{ }^{9} \mathrm{Be}\left(10^{-12}\right)$ & $\mathrm{Err}^{10} \mathrm{Be} /{ }^{9} \mathrm{Be}(\%)$ & ${ }^{10} \mathrm{Be}\left(\mathrm{at} \mathrm{g}^{-1}\right)$ & $\operatorname{Err}{ }^{10} \mathrm{Be}(\%)$ \\
\hline WK1 & 0.189 & $4.0 \%$ & 130,486 & $5.2 \%$ \\
WK2 & 0.150 & $4.8 \%$ & 104,168 & $6.3 \%$ \\
WK3 & 0.143 & $4.9 \%$ & 105,154 & $6.5 \%$ \\
WK4 & 0.200 & $4.3 \%$ & 143,742 & $5.6 \%$ \\
WK5 & 0.191 & $4.7 \%$ & 137,108 & $5.8 \%$ \\
WK6 & 0.207 & $4.9 \%$ & 149,627 & $5.8 \%$ \\
WK7 & 0.166 & $4.6 \%$ & 120,430 & $5.7 \%$ \\
WK8 & 0.160 & $4.2 \%$ & 97,816 & $5.3 \%$ \\
WK9 & 0.146 & $3.4 \%$ & 89,510 & $4.6 \%$ \\
WK10 & 0.163 & $3.3 \%$ & 102,658 & $4.5 \%$ \\
WK11 & 0.214 & $4.0 \%$ & 137,282 & $5.1 \%$ \\
WK12 & 0.197 & $3.4 \%$ & 119,454 & $5.7 \%$ \\
\hline
\end{tabular}

than the first. Both models pointed to high erosion rates at the toe of the first transect (WK7), which is rather unusual for such a topographical position.

\subsection{Correlation analysis}

A positive correlation was detectable between the soil erosion rates (obtained from ${ }^{10} \mathrm{Be}$ and ${ }^{239+240} \mathrm{Pu}$ ) and the slope gradient (Table 5), indicating, not surprisingly, higher erosion with a steeper slope. The negative correlation between the CIA values and erosion rates suggested that slope processes led to the removal of the topsoil and exposed substrates in deeper horizons that were less weathered or even had a different lithology.

\section{Discussion}

\subsection{Long- and short-term erosion rates in loess deposits}

The calculated long-term erosion rates were consistent with the terrain relief. In both transects, erosion increased in the mid-slope position, which was steeper (WK2, WK3, WK8, WK9), and mostly decreased in the lower, flatter parts of the slope. Erosion processes still occurred in the toe slope positions. However, the erosion rate was lower than in the upper parts of the slope (Fig. 2). This cross-check and agreement with independent data (Table 6) indicated that the assumption of secular equilibrium is plausible.

To determine the short-term erosion rates based on ${ }^{239+240} \mathrm{Pu}$, two conversion models were applied. The PDM showed considerably higher values (from 1.4 to $16.9 \mathrm{t}$ $\mathrm{ha}^{-1}$ year $^{-1}$ ) than the MODERN (1.2 to $10.9 \mathrm{t} \mathrm{ha}^{-1}$ year $^{-1}$ ). The PDM assumed that the activity of ${ }^{239+240} \mathrm{Pu}$ had an exponential decay function within the soil profile (Arata et al. 2016b; Calitri et al. 2020). The MODERN, however, did not make any assumptions about the ${ }^{239+240} \mathrm{Pu}$ distribution along the profile (Arata et al. 2016b) and thus may more precisely simulate the behaviour of FRN (e.g., under ploughing activities) (Alewell et al. 2017). Therefore, the results obtained using this model were deemed to be more reliable. Similar to the long-term rates determined by ${ }^{10} \mathrm{Be}$, the mid-slope positions (WK3, 4, 5, 8, 9 and 10) exhibited, in general, the highest erosion rates. Although site WK4 exhibits a relatively thick soil profile, the present-day erosion rates are high. This indicates that such high erosion rates must be a recent process, as otherwise such a thick profile could not persist. This mid-slope position has a relatively steep slope and is, therefore, particularly susceptible to erosion. In general, the measured erosion rates are high but are frequently measured or modelled for arable land in Europe (Cerdan et al. 2010).

While in situ ${ }^{10} \mathrm{Be}$ does not form any inorganic or organomineral complexes nor colloids (because this nuclide is directly produced in the crystal lattice of quartz by the interaction of cosmogenic rays), it also does not move along the soil profile. $\mathrm{Pu}$, however, accumulates in soils and sediments through atmospheric deposition. Consequently, part of $\mathrm{Pu}$ might be lost with time through pedogenetic processes or leaching. Pu has, however, an extremely low solubility and a high affinity to organic matter (Alewell et al. 2017) or is strongly adsorbed onto clay particles. In undisturbed soils, essentially, the entire inventory is concentrated in the top $30 \mathrm{~cm}$ (Ketterer et al. 2011; Iurian et al. 2015). Because the isotopes of ${ }^{239+240} \mathrm{Pu}$ are strongly adsorbed, the redistribution of these isotopes has occurred as a result of physical particle movements such as erosion (Alewell et al. 2017). Luvisols are encountered in the investigation. These soils are characterised by clay illuviation. It might be that a small part of $\mathrm{Pu}$ migrated along the soil profile due to the translocation of clay particles. This seems rather unlikely, given the fact that the content of $\mathrm{Pu}$ strongly decreases with soil depth, except in profile WK12. In this soil, however, no clay translocation was observed. Therefore, the Pu content is primarily affected by soil redistribution. 

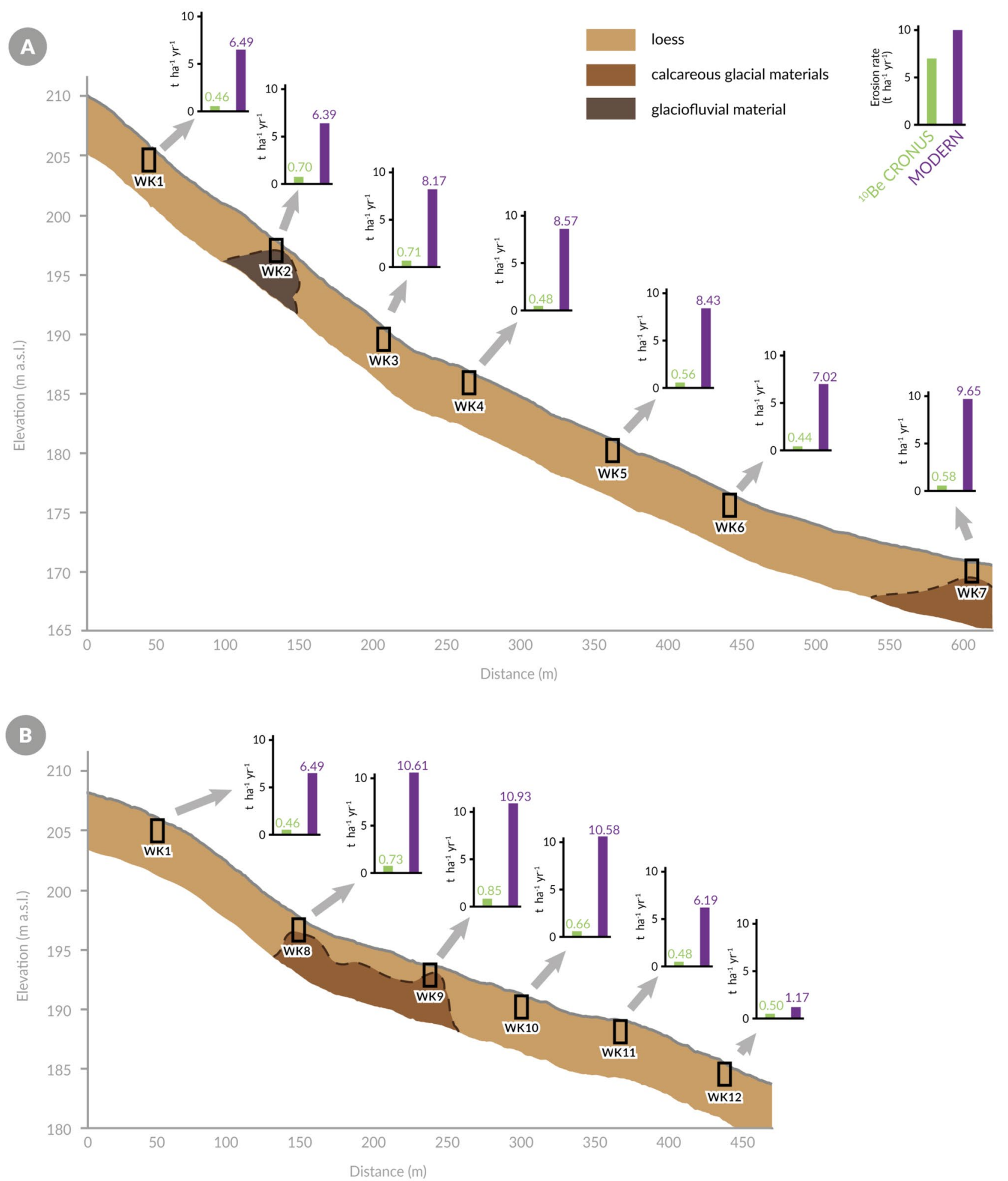

Fig. 2 Short- and long-term soil erosion rates along the studied toposequences. The thickness of the loess mantle is not to scale. Drillings were made down to $2 \mathrm{~m}$

\section{Soil erosion rates in loess landscapes}

The long-term erosion rates of the studied pedons $\left(0.44-0.85 \mathrm{t} \mathrm{ha}^{-1} \mathrm{year}^{-1}\right)$, calculated using in situ ${ }^{10} \mathrm{Be}$, were in a good agreement with values from other studies of loess landscapes using different methods (Table 6). In Germany, Dreibrodt et al. $(2010,2013)$ determined the erosion in the Early Bronze Age $\left(0.3-0.6 \mathrm{tha}^{-1} \mathrm{year}^{-1}\right)$ and of 
Table $4{ }^{239+240} \mathrm{Pu}$ activity in studied soils

\begin{tabular}{|c|c|c|c|c|}
\hline Soil profile & $\begin{array}{l}\text { Depth } \\
\text { (cm) }\end{array}$ & $\begin{array}{l}{ }^{239+240} \mathrm{Pu} \\
\left(\mathrm{Bq} \mathrm{kg}^{-1}\right)\end{array}$ & $\begin{array}{l}\mathrm{SD} \\
\left(\mathrm{Bq} \mathrm{kg}^{-1}\right)\end{array}$ & ${ }^{240} \mathrm{Pu} /{ }^{239} \mathrm{Pu}$ ratio \\
\hline \multirow[t]{4}{*}{ WK1 } & $0-25$ & 0.0802 & 0.0086 & 0.19 \\
\hline & $25-30$ & 0.0668 & 0.0065 & 0.16 \\
\hline & $30-35$ & 0.0069 & 0.0019 & 0.18 \\
\hline & $35-40$ & 0.0151 & 0.0018 & 0.13 \\
\hline \multirow[t]{5}{*}{ WK2 } & $0-20$ & 0.0515 & 0.0070 & 0.19 \\
\hline & $20-25$ & 0.0622 & 0.0067 & 0.19 \\
\hline & $25-30$ & 0.0515 & 0.0050 & 0.17 \\
\hline & $30-35$ & 0.0024 & 0.0011 & N/A \\
\hline & $35-40$ & 0.0073 & 0.0033 & 0.18 \\
\hline \multirow[t]{4}{*}{ WK3 } & $0-25$ & 0.0664 & 0.0068 & 0.19 \\
\hline & $25-30$ & 0.0070 & 0.0027 & N/A \\
\hline & $30-35$ & 0.0044 & 0.0016 & 0.20 \\
\hline & $35-40$ & 0.0353 & 0.0057 & 0.18 \\
\hline \multirow[t]{4}{*}{ WK4 } & $0-25$ & 0.0497 & 0.0094 & 0.14 \\
\hline & $25-30$ & 0.0044 & 0.0019 & 0.24 \\
\hline & $30-35$ & 0.0011 & N/A & N/A \\
\hline & $35-40$ & 0.0009 & 0.0007 & 0.28 \\
\hline \multirow[t]{4}{*}{ WK5 } & $0-25$ & 0.0740 & 0.0051 & 0.21 \\
\hline & $25-30$ & 0.0062 & 0.0024 & 0.14 \\
\hline & $30-35$ & 0.0078 & 0.0030 & 0.31 \\
\hline & $35-40$ & 0.0137 & 0.0040 & 0.28 \\
\hline \multirow[t]{4}{*}{ WK6 } & $0-25$ & 0.0694 & 0.0061 & 0.16 \\
\hline & $25-30$ & 0.0696 & 0.0079 & 0.18 \\
\hline & $30-35$ & 0.0041 & 0.0017 & 0.15 \\
\hline & $35-40$ & 0.0041 & 0.0020 & 0.25 \\
\hline \multirow[t]{4}{*}{ WK7 } & $0-25$ & 0.0666 & 0.0039 & 0.20 \\
\hline & $25-30$ & 0.0118 & 0.0025 & 0.20 \\
\hline & $30-35$ & 0.0043 & 0.0015 & 0.14 \\
\hline & $35-40$ & 0.0010 & 0.0006 & 0.09 \\
\hline \multirow[t]{5}{*}{ WK8 } & $0-20$ & 0.0531 & 0.0065 & 0.20 \\
\hline & $20-25$ & 0.0064 & 0.0020 & 0.15 \\
\hline & $25-30$ & 0.0024 & 0.0013 & 0.05 \\
\hline & $30-35$ & 0.0012 & 0.0008 & N/A \\
\hline & $35-40$ & 0.0006 & 0.0007 & N/A \\
\hline \multirow[t]{3}{*}{ WK9 } & $0-25$ & 0.0571 & 0.0054 & 0.20 \\
\hline & $25-30$ & 0.0007 & N/A & N/A \\
\hline & $30-35$ & 0.0000 & 0.0001 & N/A \\
\hline \multirow[t]{3}{*}{ WK10 } & $0-25$ & 0.0616 & 0.0093 & 0.18 \\
\hline & $25-30$ & 0.0047 & 0.0021 & N/A \\
\hline & $30-35$ & 0.0013 & 0.0007 & 0.18 \\
\hline \multirow[t]{5}{*}{ WK11 } & $0-20$ & 0.0835 & 0.0058 & 0.18 \\
\hline & $20-25$ & 0.0189 & 0.0032 & 0.17 \\
\hline & $25-30$ & 0.0527 & 0.0042 & 0.21 \\
\hline & $30-35$ & 0.0106 & 0.0032 & 0.19 \\
\hline & $35-40$ & 0.0034 & 0.0011 & 0.12 \\
\hline
\end{tabular}

Table 4 (continued)

\begin{tabular}{lclll}
\hline Soil profile & $\begin{array}{l}\text { Depth } \\
(\mathrm{cm})\end{array}$ & $\begin{array}{l}{ }^{239+240} \mathrm{Pu} \\
\left(\mathrm{Bq} \mathrm{kg}^{-1}\right)\end{array}$ & $\begin{array}{l}\mathrm{SD} \\
\left(\mathrm{Bq} \mathrm{kg}^{-1}\right)\end{array}$ & ${ }^{240} \mathrm{Pu} /{ }^{239} \mathrm{Pu}$ ratio \\
\hline WK12 & $0-5$ & 0.0804 & 0.0081 & 0.16 \\
& $5-10$ & 0.0671 & 0.0051 & 0.21 \\
& $10-15$ & 0.0815 & 0.0090 & 0.20 \\
& $15-20$ & 0.0875 & 0.0082 & 0.18 \\
& $20-25$ & 0.0944 & 0.0086 & 0.21 \\
& $25-30$ & 0.0986 & 0.0111 & 0.19 \\
& $30-35$ & 0.0937 & 0.0112 & 0.21 \\
& $35-40$ & 0.0932 & 0.0098 & 0.20 \\
$0-5$ & 0.5290 & 0.0197 & 0.21 \\
& $5-10$ & 0.3492 & 0.0147 & 0.21 \\
& $10-15$ & 0.1018 & 0.0116 & 0.20 \\
& $15-20$ & 0.0338 & 0.0062 & 0.24 \\
& $20-25$ & 0.0371 & 0.0050 & 0.21 \\
& $25-30$ & 0.0080 & 0.0034 & 0.15 \\
$30-35$ & 0.0026 & 0.0012 & 0.13 \\
$35-40$ & 0.0012 & 0.0005 & N/A \\
\hline
\end{tabular}

$S D$ standard deviation, N/A not applicable

the Late Neolithic to Bronze Age (0.4-0.5 tha ${ }^{-1}$ year $\left.^{-1}\right)$ by relating the mass of the deposited sediments to the that of the catchment area and/or by reconstructing slope cross sections. Gillijns et al. (2005) and Kołodyńska-Gawrysiak et al. (2018) analysed closed depression catchments in Belgium and Poland, respectively. The obtained erosion rate from $430 \mathrm{AD}$ to today was estimated to be $2.1 \mathrm{t} \mathrm{ha}^{-1} \mathrm{year}^{-1}$ for sites in Belgium (Gillijns et al. 2005), whereas those of the selected sites in Poland varied between 0.24 and 0.27 $\mathrm{t} \mathrm{ha}^{-1}$ year $^{-1}$ from the Late Vistulian (Weichselian) up to today (Kołodyńska-Gawrysiak et al. 2018).

The short-term erosion rates of the studied soils (1.2-10.9 t $\mathrm{ha}^{-1}$ year $^{-1}$ ), using ${ }^{239+240} \mathrm{Pu}$ as a tracer, differed from the data presented so far (Table 6). Erosion rates were also calculated for the Trzebnica Hills using USLE (Licznar and Licznar 2002; Licznar et al. 2002). These calculated rates ranged between 2.5 and $4.3 \mathrm{tha}^{-1}$ year $^{-1}$ - although these values lie within the range determined by ${ }^{239+240} \mathrm{Pu}$, they were in general a factor of 2 lower. Other studies on erosion rates in Polish loess landscapes have shown a wide variability. Poręba et al. (2019, 2015) determined soil erosion rates of 4.9 to $39.9 \mathrm{tha}^{-1} \mathrm{year}^{-1}$ using ${ }^{137} \mathrm{Cs}$ and 2.2 to $30.7 \mathrm{t} \mathrm{ha}^{-1}$ year ${ }^{-1}$ using ${ }^{210} \mathrm{~Pb}_{\mathrm{ex}}$. Rejman et al. (2008) used sediment yields over a 10-year period, obtaining erosion rates from 0.4 to $95.0 \mathrm{t} \mathrm{ha}^{-1}$ year $^{-1}$, whereas Święchowicz (2016) and Rejman and Brodowski (2010) determined with sediment yields soil losses of $47.3 \mathrm{tha}^{-1} \mathrm{year}^{-1}$ and $98.2 \mathrm{t} \mathrm{ha}^{-1}$ year $^{-1}$, respectively. Rafalska-Przysucha and Rejman (2015) assessed erosion rates of $24.3 \mathrm{t} \mathrm{ha}^{-1}$ year $^{-1}$ using 


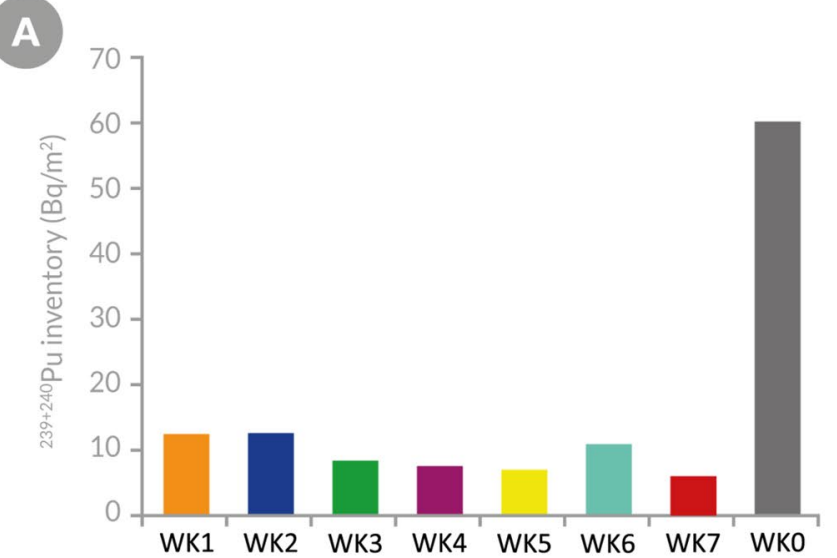

B

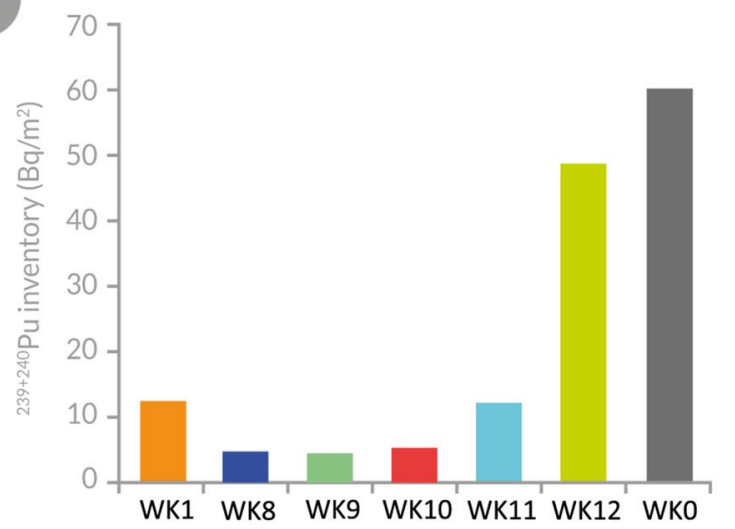

Fig. $3{ }^{239+240} \mathrm{Pu}$ inventories in transects $\mathrm{A}$ and $\mathrm{B}$

sedimentary archives from closed depressions. The discrepancies between these results might be explained by the different methods used and/or by the landscape relief. USLE involves mathematical modelling only and includes parameters that depend on precipitation and crop rotation, which change over time (Kaszubkiewicz. et al. 2011). Therefore, a direct comparison with FRN-derived erosion rates may not be practicable. The determination of erosion rates using ${ }^{137} \mathrm{Cs}$ in Central and Western Europe may be difficult because two different sources exist (nuclear weapons testing in the 1950s and 1960s and the Chernobyl accident). When using this approach, the proportions of these two sources must be determined (Alewell et al. 2017; Poręba et al. 2019). These conditions were met by the investigation of Poręba et al. (2019, 2015). The erosion rates determined with ${ }^{210} \mathrm{~Pb}_{\mathrm{ex}}$ were much higher than in our study (Poręba et al. 2019). This apparent discrepancy to our erosion rates is related to a different terrain relief and land-use intensity. Rejman et al. (2008), Rejman and Brodowski (2010) and Święchowicz (2016) measured very high erosion rates, which was likely predominantly due to an almost complete absence of vegetation on their plots. Closed depressions as an archive of soil erosion refer to Modern Times; however, in research presented by RafalskaPrzysucha and Rejman (2015), this covers a longer time span (188 year) than ${ }^{239+240} \mathrm{Pu}$ analysis.

Our data lie within the range of those from other loess areas in Europe. In Germany, the erosion rates range mostly between 2 and $10 \mathrm{t} \mathrm{ha}^{-1}$ year $^{-1}$ when using the CORINE

Table 5 Correlation between chosen characteristics of studied soils and terrain relief

\begin{tabular}{llcc}
\hline & Slope gradient & $\begin{array}{c}{ }^{239+240} \mathrm{Pu} \\
\text { erosion rates }\end{array}$ & \\
\hline & & \\
\hline CIA mean & $-0.39^{*}$ & $-0.53^{*}$ & $-0.44^{*}$ \\
Slope gradient & - & $0.59^{*}$ & $0.75^{*}$ \\
\hline
\end{tabular}

${ }^{*}$ Pearson correlation coefficient database (Cerdan et al. 2010). When using other methods such as the reconstruction of the slope cross section or by relating the mass of the deposited sediments to the catchment area, then the erosion rates are normally in the range of 3.2 and $13.3 \mathrm{t} \mathrm{ha}^{-1}$ year $^{-1}$ (Dreibrodt et al. 2010, 2013). In Belgium, analysis of the sediments in a closed depression catchment showed erosion rates from 5.5 to $9.8 \mathrm{t} \mathrm{ha}^{-1}$ year $^{-1}$ (Gillijns et al. 2005), the erosion rates from sediment yields ranged from 0.5 to $7.9 \mathrm{t} \mathrm{ha}^{-1}$ year $^{-1}$ (Verstraeten and Poesen 2001; Evrard et al. 2008), whereas with the SEDEM model (sediment delivery model) and ${ }^{137} \mathrm{Cs}$, soil losses ranging from 2.0 to $5.0 \mathrm{t} \mathrm{ha}^{-1}$ year $^{-1}$ and $3.0 \mathrm{t} \mathrm{ha}^{-1}$ year $^{-1}$ were determined, respectively (Van Rompaey et al. 2001; Van Oost et al. 2003). The relatively narrow range of erosion rates for soils on loess (Europe) may indicate the starting point of their agricultural use.

\subsection{Cross-check of long- and short-term erosion rates}

Applying isotopes that cover different time ranges along two transects has enabled a cross-check of the long- and medium-term erosion rates (Zollinger et al. 2015; Jelinski et al. 2019) but has also provided an insight into the multidirectional course and intensity of erosional processes.

The short-term erosion rates are distinctly higher (up to 10 times) than the long-term rates. This finding fits very well with the results presented in Kołodyńska-Gawrysiak et al. (2018), proving that, since prehistoric times, soil erosion rates $\left(0.39-0.57 \mathrm{tha}^{-1}\right.$ year $\left.^{-1}\right)$ have increased by a factor of almost 10 compared to the time span between the Middle Ages and Modern Times (3.7-5.9 $\mathrm{t} \mathrm{ha}^{-1}$ year $^{-1}$ ).

Moreover, the results from in situ ${ }^{10} \mathrm{Be}$ and ${ }^{239+240} \mathrm{Pu}$ analyses show the intensity of erosion processes along hillslopes. The pedons located in mid-slope positions experienced 
Table 6 Long- and medium-term soil erosion rates from loess regions

\begin{tabular}{|c|c|c|c|c|c|}
\hline No & Location & Time scale & Method & $\begin{array}{l}\text { Soil erosion rate } \\
\left(\mathrm{t} \mathrm{ha} \mathrm{hear}^{-1}\right)\end{array}$ & References \\
\hline \multirow[t]{2}{*}{1.} & \multirow[t]{2}{*}{ Germany, Salzmünde } & $\begin{array}{l}\text { Early bronze age } \\
\text { Modern times }\end{array}$ & $\begin{array}{l}\text { Relating mass of deposited } \\
\text { sediments to superficial } \\
\text { catchment area; }\end{array}$ & $\begin{array}{l}0.4-0.6 \\
4.4-13.3\end{array}$ & \multirow[t]{2}{*}{ Dreibrodt et al. (2013) } \\
\hline & & $\begin{array}{l}\text { Early bronze age } \\
\text { Modern times }\end{array}$ & $\begin{array}{l}\text { Reconstruction of the slope } \\
\text { cross section }\end{array}$ & $\begin{array}{l}0.3-0.4 \\
3.2-9.5\end{array}$ & \\
\hline 2. & $\begin{array}{l}\text { Germany, Kleiner Tor- } \\
\text { nowsee }\end{array}$ & $\begin{array}{l}\text { Late Neolith-Bronze Age } \\
\text { Modern times }\end{array}$ & $\begin{array}{l}\text { Reconstruction of slope } \\
\text { cross section }\end{array}$ & $\begin{array}{l}0.4-0.5 \\
3.2-10.4\end{array}$ & Dreibrodt et al. (2010) \\
\hline 3. & Germany, Lower Saxony & Modern times & Mapping erosion events & 1.7 & $\begin{array}{l}\text { Steinhoff-Knopp and Burkhard } \\
\text { (2018) }\end{array}$ \\
\hline 4. & Germany, Chemnitz & Modern times & $\begin{array}{l}\text { CORINE database, based } \\
\text { on sediment plots }\end{array}$ & $5-10$ & \multirow[t]{2}{*}{ Cerdan et al. (2010) } \\
\hline 5. & Belgium, Leuven & Modern times & $\begin{array}{l}\text { CORINE database, based } \\
\text { on sediment plots }\end{array}$ & $2-5$ & \\
\hline 6. & Belgium, Zaventem & Modern times & Sediment yields & 7.9 & Verstraeten and Poesen (2001) \\
\hline 7. & Belgium, Bertem & $\begin{array}{l}\text { Modern times } \\
\text { Since 430AD-until today }\end{array}$ & $\begin{array}{l}\text { Closed depression catch- } \\
\text { ment }\end{array}$ & $\begin{array}{l}5.5-9.8 \\
2.1\end{array}$ & Gillijns et al. (2005) \\
\hline 8. & Belgium, Dijle & Modern times & SEDEM & $2.0-5.0$ & Van Rompaey et al (2001) \\
\hline 9. & Belgium, Huldenberg & Modern times & ${ }^{137} \mathrm{Cs}$ & 3.0 & Van Oost et al. (2003) \\
\hline 10. & Belgium, Velm & Modern times & Sediment yield & $0.5-3.5$ & Evrard et al. (2008) \\
\hline 11. & France, Austreberthe & Modern times & Water erosion map & 3.3 & Delmas et al. (2012) \\
\hline 12. & Poland, Trzebnica Hills & Modern times & USLE & $2.5-4.3$ & Licznar and Licznar (2002) \\
\hline 13. & Poland, Bogucin & Modern times & Runoff plots & $0.4-10.8$ & Rejman et al. (2008) \\
\hline 14. & Poland, Czesławice & Modern times & Runoff plots & $10.8-96.1$ & \\
\hline 15. & Poland, Brzesko Foreland & Modern times & Runoff plots & 47.3 & Święchowicz (2016) \\
\hline 16. & Poland, Bogucin & Modern times & Runoff plots & 98.2 & Rejman and Brodowski (2010) \\
\hline 17. & Poland, Świerklany & Modern times & ${ }^{137} \mathrm{Cs}$ & 26.7 & Poręba et al. (2015) \\
\hline 18. & Poland, Biedrzykowice & Modern times & ${ }^{137} \mathrm{Cs}$ & $4.9-39.9$ & Poręba et al. (2019) \\
\hline 19. & Poland, Biedrzykowice & Modern times & ${ }^{210} \mathrm{~Pb}_{\mathrm{ex}}$ & $2.2-30.7$ & \\
\hline 20. & Poland, Tomaszowice & Late Vistulian-until today & $\begin{array}{l}\text { Closed depressions catch- } \\
\text { ment }\end{array}$ & $0.24-0.27$ & $\begin{array}{l}\text { Kołodyńska-Gawrysiak et al. } \\
\text { (2018) }\end{array}$ \\
\hline \multirow[t]{3}{*}{21.} & \multirow[t]{3}{*}{ Poland, Rąblów } & $\begin{array}{l}\text { Prehistoric times } \\
\text { Early Neolithic-Middle } \\
\text { Bronze Age }\end{array}$ & \multirow[t]{3}{*}{$\begin{array}{l}\text { Closed depressions catch- } \\
\text { ment }\end{array}$} & $\begin{array}{l}0.39-0.57 \\
0.3-0.5\end{array}$ & \\
\hline & & $\begin{array}{l}\text { Early Middle Ages-until } \\
\text { today }\end{array}$ & & $3.8-4.1$ & \\
\hline & & $\begin{array}{l}\text { Middle Ages-Modern } \\
\text { Times }\end{array}$ & & $3.7-5.9$ & \\
\hline 22. & Poland, Bogucin & Modern times & $\begin{array}{l}\text { Closed depression catch- } \\
\text { ment }\end{array}$ & 24.3 & $\begin{array}{l}\text { Rafalska-Przysucha and Rejman } \\
\text { (2015) }\end{array}$ \\
\hline
\end{tabular}

SEDEM sediment delivery model

generally higher erosion rates. This is especially evident in the second transect where the soil morphology exhibits features that are strongly linked to erosion, such as the absence of an E horizon and the incorporation of the Bt into the Ap horizon. Although the soil WK1 apparently looks undisturbed, the CIA values (Table S1) indicate that the profile is disturbed (the CIA value should decrease with increasing soil depth which is, however, not the case here).
Usually, in the toe slope position, eroded material is deposited and, consequently, accumulation is expected (Henkner et al. 2017). At our sites, however, erosion was still measurable here. This highlights that intense erosion occurred along the studied slopes. During heavy rain, the material was eroded from the entire length of the slope, even from sites where the slope gradient was decreased (Fig. 4). The erosion rates have increased during the last few decades 


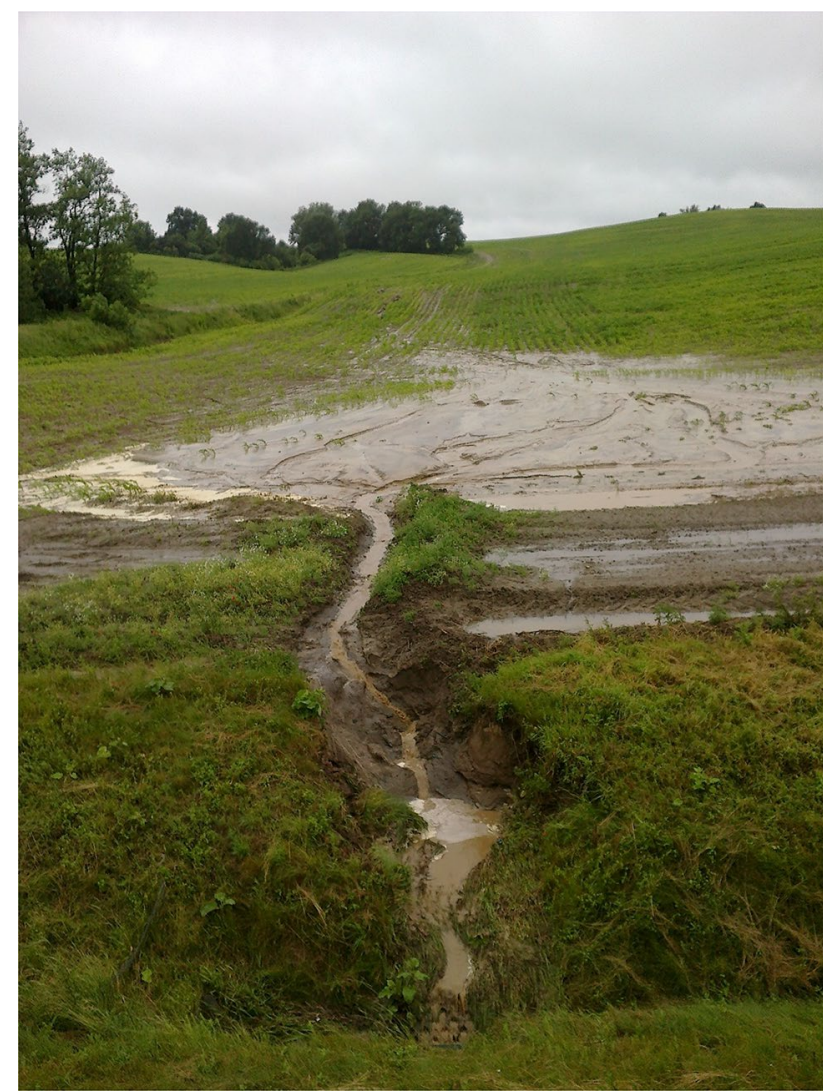

Fig. 4 Effects of soil erosion in the study area after intensive rainfall. Silt fine particles are visible as a wide yellowish-brown "plate" at the toe slope section and small erosion channels caused by concentrated runoff

even at sites with a low slope gradient, such as WK7 and WK12 (Table 1). The morphology of site WK12 indicated the accumulation of colluvial material, but the recent erosion rates were 2.5 times higher than the long-term rates. At site WK7, this increase was almost by a factor of 20. The fact that the soil at WK7 experienced higher erosion rates than at WK12 may be due to the protective effect of redcurrants (Ribes spicatum Robson) for a few years at the latter site, which may have improved soil resilience. A further explanation is that the position of profile WK7 is in the marginal zone of the hill. There, periodic surface runoff may have increased the erosion rates. In general, the high rates of shortterm erosion are related to the intensification and mechanisation of agriculture (Foucher et al. 2014; Kopittke et al. 2019; Poręba et al. 2019), although agricultural activities alone may be responsible for the increase erosion rates. Climate change might be an additional factor causing higher erosion rates because it is giving rise to drier soils, fewer rainfall events, but increasing event intensity (Routschek et al. 2014; Zollinger et al. 2015; Zádorová and Penížek 2018). Kundzewicz and Matczak (2012) also noted an increase in rainfall intensity in Poland. The effect of climate change on soil erosion can, however, not be further quantified.
Alewell et al. (2015) posited that tolerable soil erosion rates must be less than or equal to the soil production rates, otherwise the soil would start to degrade. Because soil production rates strongly decrease with the age of a soil, also the tolerable erosion rates (as a soil destructive process) decrease with time. Most of the European soils in the lowlands have an age of $>10 \mathrm{kyr}$. Tolerable erosion rates for soils in alpine climates and having a surface age of $>10 \mathrm{kyr}$ are between 0.5 and $1 \mathrm{t} \mathrm{ha}^{-1}$ year $^{-1}$ (Alewell et al. 2015). Also, Verheijen et al. (2009) showed that tolerable erosion rates for European soils should be less than $1 \mathrm{t} \mathrm{ha}^{-1}$ year $^{-1}$. Mediterranean to alpine soils show all after $10 \mathrm{kyr}$ strongly reduced formation rates $\left(<1 \mathrm{t} \mathrm{ha}^{-1}\right.$ year $^{-1}$; Egli et al. 2014). Consequently, tolerable erosion rates in the range of 0.5 to $1 \mathrm{t} \mathrm{ha}^{-1}$ year $^{-1}$ are also applicable to our investigation area. Only the long-term erosion rates in our investigated area were in this range or below. However, the short-term erosion rates were 10-22 times higher and thus far beyond any tolerable rates. Therefore, the present-day soil loss considerably exceeds soil production and will lead to significant soil thinning and reduce its productivity (Alewell et al. 2015).

\section{Conclusions}

The long-term erosion rates of loess landscapes calculated using in situ ${ }^{10} \mathrm{Be}$ were in agreement with the results from sedimentary archives of closed depressions and slope cross-section reconstructions. The short-term erosion rates determined using ${ }^{239+240} \mathrm{Pu}$ differed from previously published results in Poland that used other approaches $\left({ }^{137} \mathrm{Cs}\right.$, USLE, sediment yields, closed depressions). The main reasons for these discrepancies are the differences in conceptual approach and local terrain variability, such as topography, land-use modifications over time, etc. The recent erosion rates determined for the investigated sites using ${ }^{239+240} \mathrm{Pu}$ are comparable to those from loess sites in Germany, Belgium and France. The short-term erosion rates are up to more than one order of magnitude higher than the long-term rates. This indicates the strong recent impact of agriculture and probably also climate change. The current soil erosion values are far above any tolerable erosion rate. Therefore, the soil is strongly imbalanced, resulting in drastic soil thinning. From a methodological point of view, the use of in situ ${ }^{10} \mathrm{Be}$ and ${ }^{239+240} \mathrm{Pu}$ can provide insights into the temporal evolution of soil erosion rates, although loess soils have problematic characteristics, such as clay migration, that may affect their determination.

Electronic supplementary material The online version of this article (https://doi.org/10.1007/s11368-021-02996-x) contains supplementary material, which is available to authorized users.

Acknowledgements The authors are grateful to Krzyszt of Papuga and Paweł Jezierski for their help during the fieldwork and Cezary Kabała 
for the photographic documentation. In addition, we are grateful to two unknown reviewers for the helpful comments on an earlier version of the manuscript. We are also grateful to the owners of the fields: Lech Bienias, Kazimierz Kwaśniewski, Jerzy Placha, Czesław Waszuk, for enabling conducting these research.

Funding This research was financed by the National Science Center (Poland) project number 2018/29/B/ST10/01282 (Opus 15) and by The Polish National Agency for Academic Exchange (POWR.03.03.00-00-PN13/18).

Open Access This article is licensed under a Creative Commons Attribution 4.0 International License, which permits use, sharing, adaptation, distribution and reproduction in any medium or format, as long as you give appropriate credit to the original author(s) and the source, provide a link to the Creative Commons licence, and indicate if changes were made. The images or other third party material in this article are included in the article's Creative Commons licence, unless indicated otherwise in a credit line to the material. If material is not included in the article's Creative Commons licence and your intended use is not permitted by statutory regulation or exceeds the permitted use, you will need to obtain permission directly from the copyright holder. To view a copy of this licence, visit http://creativecommons.org/licenses/by/4.0/.

\section{References}

Alewell C, Egli M, Meusburger K (2015) An attempt to estimate tolerable soil erosion rates by matching soil formation with denudation in Alpine grasslands. J Soils Sediments 15:1383-1399. https://doi. org/10.1007/s11368-014-0920-6

Alewell C, Meusburger K, Juretzko G et al (2014) Suitability of $239+240 \mathrm{Pu}$ and $137 \mathrm{Cs}$ as tracers for soil erosion assessment in mountain grasslands. Chemosphere 103:274-280. https://doi.org/ 10.1016/j.chemosphere.2013.12.016

Alewell C, Pitois A, Meusburger K et al (2017) 239+240 Pu from "contaminant" to soil erosion tracer: where do we stand? Earth-Science Rev 172:107-123. https://doi.org/10.1016/j.earscirev.2017.07.009

Altermann M, Rinklebe J, Merbach I et al (2005) Chernozem - soil of the year 2005. J Plant Nutr Soil Sci 168:725-740. https://doi.org/ 10.1002/jpln.200521814

Anioł-Kwiatkowska J (1998) Endangered and rare segetal species in the microregion Trzebnica Hills. Acta Univ Lodz 13:169-176

Arata L, Alewell C, Frenkel E et al (2016a) Modelling deposition and erosion rates with radioNuclides (MODERN) - part 2: a comparison of different models to convert $239+240 \mathrm{Pu}$ inventories into soil redistribution rates at unploughed sites. J Environ Radioact 162-163:97-106. https://doi.org/10.1016/j.jenvrad.2016.05.009

Arata L, Meusburger K, Frenkel E et al (2016b) Modelling deposition and erosion rates with radionuclides (MODERN) - part 1: a new conversion model to derive soil redistribution rates from inventories of fallout radionuclides. J Environ Radioact 162-163:45-55. https://doi.org/10.1016/j.jenvrad.2016.05.008

Bac S, Rojek M (2012) Meteorologia i klimatologia w inzynierii środowiska. Wydawnictwo Uniwersytetu Przyrodniczego we Wrocławiu, Wrocław

Balco G, Stone JO, Lifton NA, Dunai TJ (2008) A complete and easily accessible means of calculating surface exposure ages or erosion rates from 10Be and 26Al measurements. Quat Geochronol 3:174-195. https://doi.org/10.1016/j.quageo.2007.12.001

Calitri F, Sommer M, Norton K et al (2019) Tracing the temporal evolution of soil redistribution rates in an agricultural landscape using 239+240 Pu and $10 \mathrm{Be}$. Earth Surf Process Landforms esp.4612. https://doi.org/10.1002/esp.4612
Calitri F, Sommer M, van der Meij MW, Egli M (2020) Soil erosion along a transect in a forested catchment: Recent or ancient processes? CATENA 194:104683. https://doi.org/10.1016/j.catena.2020.104683

Cerdan O, Govers G, Le Bissonais Y et al (2010) Rates and spatial variation of soil erosion in Europe: a study based on erosion plot data. Geomorphology 122:167-177. https://doi.org/10.1016/j. geomorph.2010.06.011

Chengde S, Beer J, Tungsheng L et al (1992) ${ }^{10} \mathrm{Be}$ in Chinese loess. Earth Planet Sci Lett 109:169-177. https://doi.org/10.1016/ 0012-821X(92)90081-6

Christl M, Vockenhuber C, Kubik PW et al (2013) The ETH Zurich AMS facilities: performance parameters and reference materials. Nucl Instruments Methods Phys Res Sect B Beam Interact with Mater Atoms 294:29-38. https://doi.org/10.1016/j.nimb.2012.03.004

De Vos W, Tarvainen T (2006) Interpretation of Geochemical Maps, Additional Tables, Figures, Maps and Related Publications. In: De Vos W, Tarvainen T (ed) Geochemical Atlas of Europe. Part 2, Otamedia Oy, Espoo, pp. 690

Delmas M, Pak LT, Cerdan O et al (2012) Erosion and sediment budget across scale: A case study in a catchment of the European loess belt. J Hydrol 420-421:255-263. https://doi.org/10.1016/j.jhydrol. 2011.12.008

Dreibrodt S, Jarecki H, Lubos C et al (2013) Holocene soil formation and soil erosion at a slope beneath the Neolithic earthwork Salzmünde (Saxony-Anhalt, Germany). CATENA 107:1-14. https://doi.org/10.1016/j.catena.2013.03.002

Dreibrodt S, Lomax J, Nelle O et al (2010) Are mid-latitude slopes sensitive to climatic oscillations? Implications from an Early Holocene sequence of slope deposits and buried soils from eastern Germany. Geomorphology 122:351-369. https://doi.org/10. 1016/j.geomorph.2010.05.015

Dyjor S (1970) Seria poznańska w Polsce Zachodniej. Kwart Geol 14:819-834

Dyjor S, Kościówko H (1982) Formacja trzeciorzędowa południowozachodniej Polski i związane z nią perspektywy wybranych surowców. Biul Inst Geol 341

Egli M, Norton K, Dahms D (2014) Soil formation rates on silicate parent material in alpine environments: different approaches, different results? Geoderma 213:320-333

Evrard O, Vandaele K, van Wesemael B, Bielders CL (2008) A grassed waterway and earthen dams to control muddy floods from a cultivated catchment of the Belgian loess belt. Geomorphology 100:419-428. https://doi.org/10.1016/j.geomorph.2008.01.010

FAO (ed) (2006) Guidelines for soil description, 4rd edn. FAO, Rome

Foucher A, Salvador-Blanes S, Evrard O et al (2014) Increase in soil erosion after agricultural intensification: evidence from a lowland basin in France. Anthropocene 7:30-41. https://doi.org/10.1016/j. ancene.2015.02.001

Gerlach R, Fischer P, Eckmeier E, Hilgers A (2012) Buried dark soil horizons and archaeological features in the Neolithic settlement region of the Lower Rhine area, NW Germany: Formation, geochemistry and chronostratigraphy. Quat Int 265:191-204. https:// doi.org/10.1016/j.quaint.2011.10.007

Gillijns K, Poesen J, Deckers J (2005) On the characteristics and origin of closed depressions in loess-derived soils in Europe-a case study from central Belgium. CATENA 60:43-58. https://doi.org/ 10.1016/j.catena.2004.10.001

Glina B, Waroszewski J, Kabal C (2014) Water retention of the loessderived Luvisols with lamellic illuvial horizon in the Trzebnica Hills (SW Poland). Soil Sci Annu 65:18-24. https://doi.org/10. 2478/ssa-2014-0003

Golosov VN, Collins AL, Dobrovolskaya NG et al (2021) Soil loss on the arable lands of the forest-steppe and steppe zones of European Russia and Siberia during the period of intensive agriculture. Geoderma 381:114678. https://doi.org/10.1016/j.geoderma.2020. 114678 
Graly JA, Bierman PR, Reusser LJ, Pavich MJ (2010) Meteoric 10Be in soil profiles - a global meta-analysis. Geochim Cosmochim Acta 74:6814-6829. https://doi.org/10.1016/j.gca.2010.08.036

Gu ZY, Lal D, Liu TS et al (1997) Weathering histories of Chinese loess deposits based on uranium and thorium series nuclides and cosmogenic 10 Be. Geochim Cosmochim Acta 61:5221-5231. https://doi.org/10.1016/S0016-7037(97)00313-X

Guzmán G, Laguna A, Cañasveras JC et al (2015) Study of sediment movement in an irrigated maize-cotton system combining rainfall simulations, sediment tracers and soil erosion models. J Hydrol 524:227-242. https://doi.org/10.1016/j.jhydrol.2015.02.033

Haase D, Fink J, Haase G et al (2007) Loess in Europe-its spatial distribution based on a European Loess Map, scale 1:2,500,000. Quat Sci Rev 26:1301-1312. https://doi.org/10.1016/j.quascirev. 2007.02.003

Henkner J, Ahlrichs JJ, Downey S et al (2017) Archaeopedology and chronostratigraphy of colluvial deposits as a proxy for regional land use history (Baar, southwest Germany). CATENA 155:93113. https://doi.org/10.1016/j.catena.2017.03.005

Hidy AJ, Gosse JC, Pederson JL et al (2010) A geologically constrained Monte Carlo approach to modeling exposure ages from profiles of cosmogenic nuclides: an example from Lees Ferry, Arizona. Geochemistry Geophys Geosystems 11:Q0AA10. https://doi.org/ 10.1029/2010GC003084

Iurian A-R, Phaneuf MO, Mabit L (2015) Mobility and bioavailability of radionuclides in soils. In: Walther C, Gupta DK (ed) Radionuclides in the environment: influence of chemical speciation and plant uptake on radionuclide migration. Springer, pp 37-59

IUSS Working Group WRB (2015) World Reference Base for soil 721 resources 2014, update 2015 international soil classification 722 system for naming soils and creating legends for soil maps. World 723 soil resources reports no. 106. FAO, Rome

Jagercikova M, Cornu S, Bourlès D et al (2015) Understanding longterm soil processes using meteoric 10Be: A first attempt on loessic deposits. Quat Geochronol 27:11-21. https://doi.org/10.1016/j. quageo.2014.12.003

Jary Z (1996) Chronostratygrafia oraz warunki sedymentacji lessów południowo-zachodniej Polski na przykładzie Płaskowyżu Głubczyckiego i Wzgórz Trzebnickich. Studia Geograficzne LXIII Uniwersytetu Wrocławskiego, Wrocław.pdf

Jary Z, Ciszek D (2013) Late Pleistocene loess-palaeosol sequences in Poland and western Ukraine. Quat Int 296:37-50. https://doi.org/ 10.1016/j.quaint.2012.07.009

Jelinski NA, Campforts B, Willenbring JK et al (2019) Meteoric beryllium-10 as a tracer of erosion due to postsettlement land use in West-Central Minnesota, USA. J Geophys Res Earth Surf 124:874-901. https://doi.org/10.1029/2018JF004720

Kabała C, Marzec M (2010) Vertical and spatial diversity of grain-size distribution in Luvisols developed from loess in south-western Poland. Rocz Glebozn LXI:52-64

Kabała C, Musztyfaga E, Gałka B, et al (2016) Conversion of soil $\mathrm{pH} 1: 2.5 \mathrm{KCl}$ and 1:2.5 $\mathrm{H} 2 \mathrm{O}$ to $1: 5 \mathrm{H} 2 \mathrm{O}$ : conclusions for soil management, environmental monitoring, and international soil databases. Polish J Environ Stud 25:647-653. https://doi.org/10. 15244/pjoes/61549

Kabała C, Przybył A, Krupski M et al (2019) Origin, age and transformation of Chernozems in northern Central Europe - new data from Neolithic earthen barrows in SW Poland. CATENA 180:83102. https://doi.org/10.1016/j.catena.2019.04.014

Kaszubkiewicz. J, Tasz W, Kawałko D, Serafin R (2011) USLE model simplification proposal for application in a small agricultural catchment area. Rocz Glebozn LXII:75-81

Ketterer ME, Hafer KM, Link CL et al (2004) Resolving global versus local/regional $\mathrm{Pu}$ sources in the environment using sector ICPMS. J Anal at Spectrom 19:241-245. https://doi.org/10.1039/ B302903D
Ketterer ME, Zheng J, Yamada M (2011) Applications of transuranics as tracers and chronometers in the environment. In: Baskaran M (ed.) Handbook of environmental isotope geochemistry, Advances in Isotope Geochemistry. Springer, pp. 395-417. https://doi.org/ 10.1007/978-3-642-10637-8_20

Kohl CP, Nishiizumi K (1992) Chemical isolation of quartz for measurement of in-situ-produced cosmogenic nuclides. Geochim Cosmochim Acta 56:3583-3587. https://doi.org/10.1016/00167037(92)90401-4

Kołodyńska-Gawrysiak R, Poesen J, Gawrysiak L (2018) Assessment of long-term Holocene soil erosion rates in Polish loess areas using sedimentary archives from closed depressions. Earth Surf Process Landforms 43:978-1000. https://doi.org/10.1002/esp. 4296

Kopittke PM, Menzies NW, Wang P et al (2019) Soil and the intensification of agriculture for global food security. Environ Int 132:105078. https://doi.org/10.1016/j.envint.2019.105078

Krzyszkowski D (1993) Pleistocene stratigraphy near Trzebnica, Silesian Rampart, Southwestern Poland. Bull Pol Acad Sci

Kundzewicz ZW, Matczak P (2012) Climate change regional review: Poland. Wiley Interdiscip Rev Clim Chang 3:297-311. https:// doi.org/10.1002/wcc. 175

Labaz B, Musztyfaga E, Waroszewski J et al (2018) Landscape-related transformation and differentiation of Chernozems - catenary approach in the Silesian Lowland, SW Poland. CATENA 161:6376. https://doi.org/10.1016/j.catena.2017.10.003

Lehmkuhl F, Nett JJ, Pötter S et al (2020) Loess landscapes of Europe mapping, geomorphology, and zonal differentiation Earth-Science Rev 103496 https://doi.org/10.1016/j.earscirev.2020.103496

Licznar M, Kowaliński S, Drozd J (1981) Changes of some physical properties of soils of the głubczyce plateau under the water erosion effect. Rocz Glebozn XXXII:45-52

Licznar M, Licznar P (2002) Erodibility of Trzebnica Hills loessive soils. Zesz Probl Postępów Nauk Rol 487:129-136

Licznar P, Sasik J, Żmuda R (2002) Prognozowanie erozji wodnej w małych zlewniach rolniczych Wzgórz Trzebnickich. Zesz Probl Postępów Nauk Rol 487:137-146

Licznar S, Kowaliński S, Licznar M (1988) Zastosowanie metod mikromorfologicznych i submikromorfologicznych w badaniu gleb erodowanych. Rocz Glebozn 39:21-34

Loba A, Sykuła M, Kierczak J et al (2020) In situ weathering of rocks or aeolian silt deposition: key parameters for verifying parent material and pedogenesis in the Opawskie Mountains-a case study from SW Poland. J Soils Sediments 20:435-451. https:// doi.org/10.1007/s11368-019-02377-5

McLennan SM (2001) Relationships between the trace element composition of sedimentary rocks and upper continental crust. Geochemistry, Geophys Geosystems 2:n/a-n/a. https://doi.org/10. 1029/2000GC000109

Meusburger K, Mabit L, Ketterer M et al (2016) A multi-radionuclide approach to evaluate the suitability of $239+240 \mathrm{Pu}$ as soil erosion tracer. Sci Total Environ 566-567:1489-1499. https://doi.org/10. 1016/j.scitotenv.2016.06.035

Muhs DR (2013) The geologic records of dust in the quaternary. Aeolian Res 9:3-48. https://doi.org/10.1016/j.aeolia.2012.08.001

Musso A, Ketterer ME, Greinwald K et al (2020) Rapid decrease of soil erosion rates with soil formation and vegetation development in periglacial areas. Earth Surf Process Landforms 45:2824-2839. https://doi.org/10.1002/esp.4932

Nesbitt HW, Young GM (1982) Early Proterozoic climates and plate motions inferred from major element chemistry of lutites. Nature 299:715-717. https://doi.org/10.1038/299715a0

Nishiizumi K, Imamura M, Caffee MW et al (2007) Absolute calibration of 10Be AMS standards. Nucl Instruments Methods Phys Res Sect B Beam Interact with Mater Atoms 258:403-413. https://doi. org/10.1016/j.nimb.2007.01.297 
Pachucki C (1952) Badania geologiczne na arkuszach 1:100 000 Trzebnica i Syców. Biul Inst Geol, 66:355-294

Pasquini AI, Campodonico VA, Rouzaut S, Giampaoli V (2017) Geochemistry of a soil catena developed from loess deposits in a semiarid environment, Sierra Chica de Córdoba, central Argentina. Geoderma 295:53-68. https://doi.org/10.1016/j.geoderma.2017.01.033

Poręba G, Śnieszko Z, Moska P et al (2019) Interpretation of soil erosion in a Polish loess area using OSL, 137Cs, 210Pbex, dendrochronology and micromorphology - case study: Biedrzykowice site (s Poland). Geochronometria 46:57-78. https://doi.org/10. 1515/geochr-2015-0109

Poręba G, Śnieszko Z, Moska P (2011) Some aspects of age assessment of Holocene loess colluvium: OSL and 137Cs dating of sediment from Biała agricultural area, South Poland. Quat Int 240:44-51. https://doi.org/10.1016/j.quaint.2011.02.005

Poręba GJ, Śnieszko Z, Moska P (2015) Application of OSL dating and $137 \mathrm{Cs}$ measurements to reconstruct the history of water erosion: a case study of a Holocene colluvium in Świerklany, south Poland. Quat Int 374:189-197. https://doi.org/10.1016/j.quaint. 2015.04.004

Rafalska-Przysucha A, Rejman J (2015) Assessment of soil erosion in the catchment of two combined closed depressions in the Naleczow Plateau (Lublin Upland). Acta Agrophysica 22:91-101.

Rejman J, Brodowski R (2010) Evaluation of water erosion under sugar beet and spri wheat on loess soil on runoff plots. Prace i Studia Geograficzne 45:215-228

Rejman J, Brodowski R, Iglik I (2008) Annual variations of soil erodibility of silt loam developed from loess based on 10-years runoff plot studies. Ann Warsaw Univ Life Sci - SGGW L Reclam 39:77-83. https://doi.org/10.2478/v10060-008-0007-4

Rickson RJ (2014) Can control of soil erosion mitigate water pollution by sediments? Sci Total Environ 468-469:1187-1197. https://doi. org/10.1016/j.scitotenv.2013.05.057

Routschek A, Schmidt J, Kreienkamp F (2014) Impact of climate change on soil erosion - a high-resolution projection on catchment scale until 2100 in Saxony/Germany. CATENA 121:99-109. https://doi. org/10.1016/j.catena.2014.04.019

Sartori M, Evans ME, Heller F et al (2005) The last glacial/interglacial cycle at two sites in the Chinese Loess Plateau: mineral magnetic, grain-size and 10Be measurements and estimates of palaeoprecipitation. Palaeogeogr Palaeoclimatol Palaeoecol 222:145-160. https://doi.org/10.1016/j.palaeo.2005.03.013

Schaetzl RJ, Attig JW (2013) The loess cover of northeastern Wisconsin. Quat Res 79:199-214. https://doi.org/10.1016/j.yqres.2012. 12.004

Steinhoff-Knopp B, Burkhard B (2018) Soil erosion by water in Northern Germany: long-term monitoring results from Lower Saxony. Catena 165:299-309. https://doi.org/10.1016/j.catena.2018.02. 017

Święchowicz J (2016) Susceptibility to water erosion soils derived from loess-like deposits (Brzesko Foreland, Southern Poland). In: Święchowicz J, Michno A (ed) Wybrane zagadnienia geomorfologii eolicznej. Monografia dedykowana dr hab. Bogdanie Izmaiłow w 44. rocznicę pracy naukowej. IGiGP UJ, Kraków, pp. 332-366

Świtoniak M, Mroczek P, Bednarek R (2016) Luvisols or Cambisols? Micromorphological study of soil truncation in young morainic landscapes - case study: Brodnica and Chełmno Lake Districts (North Poland). CATENA 137:583-595. https://doi.org/10.1016/j. catena.2014.09.005

Van Oost K, Govers G, Van Muysen W (2003) A process-based conversion model for caesium-137 derived erosion rates on agricultural land: an integrated spatial approach. Earth Surf Process Landforms 28:187-207. https://doi.org/10.1002/esp.446

van Reeuwijk L (2002) Procedures for soil analysis, 6th edn. Wageningen, ISRIC
Van Rompaey AJJ, Verstraeten G, Van Oost K et al (2001) Modelling mean annual sediment yield using a distributed approach. Earth Surf Process Landforms 26:1221-1236. https://doi.org/10.1002/esp.275

Verheijen FGA, Jones RJA, Rickson RJ, Smith CJ (2009) Tolerable versus actual soil erosion rates in Europe. Earth-Science Rev 94:23-38

Verstraeten G, Poesen J (2001) Factors controlling sediment yield from small intensively cultivated catchments in a temperate humid climate. Geomorphology 40:123-144. https://doi.org/10.1016/ S0169-555X(01)00040-X

von Blanckenburg F, Belshaw NS, O’Nions RK (1996) Separation of ${ }^{9} \mathrm{Be}$ and cosmogenic ${ }^{10} \mathrm{Be}$ from environmental materials and SIMS isotope dilution analysis. Chem Geol 129:93-99. https://doi.org/ 10.1016/0009-2541(95)00157-3

Walling DE, Quine TA (1990) Calibration of caesium-137 measurements to provide quantitative erosion rate data. L Degrad Dev 2:161-175. https://doi.org/10.1002/ldr.3400020302

Waroszewski J, Egli M, Brandová D et al (2018) Identifying slope processes over time and their imprint in soils of medium-high mountains of Central Europe (the Karkonosze Mountains, Poland). Earth Surf Process Landforms 43:1195-1212. https://doi.org/10. 1002/esp.4305

Willenbring JK, von Blanckenburg F (2010) Meteoric cosmogenic beryllium-10 adsorbed to river sediment and soil: applications for Earth-surface dynamics. Earth-Science Rev 98:105-122. https:// doi.org/10.1016/j.earscirev.2009.10.008

Wyshnytzky CE, Ouimet WB, McCarthy J et al (2015) Meteoric 10Be, clay, and extractable iron depth profiles in the Colorado Front Range: implications for understanding soil mixing and erosion. CATENA 127:32-45. https://doi.org/10.1016/j.catena.2014.12.008

$\mathrm{Xu}$ Y, Qiao J, Pan S et al (2015) Plutonium as a tracer for soil erosion assessment in northeast China. Sci Total Environ 511:176-185. https://doi.org/10.1016/j.scitotenv.2014.12.006

Yang MY, Tian JL, Liu PL (2006) Investigating the spatial distribution of soil erosion and deposition in a small catchment on the Loess Plateau of China, using 137Cs. Soil Tillage Res 87:186-193. https://doi.org/10.1016/j.still.2005.03.010

Zádorová T, Penížek V (2018) Formation, morphology and classification of colluvial soils: a review. Eur J Soil Sci 69:577-591. https:// doi.org/10.1111/ejss.12673

Zhang K, Pan S, Liu Z et al (2018) Vertical distributions and source identification of the radionuclides $239 \mathrm{Pu}$ and $240 \mathrm{Pu}$ in the sediments of the Liao River estuary, China. J Environ Radioact 181:78-84. https://doi.org/10.1016/j.jenvrad.2017.10.016

Zhang X, Higgit DL, Walling DE (1990) A preliminary assessment of the potential for using caesium-137 to estimate rates of soil erosion in the Loess Plateau of China. Hydrol Sci J 35:243-252. https://doi.org/10.1080/02626669009492427

Zhou W, Xie X, Beck W et al (2015) Recent progress of 10Be tracer studies in Chinese loess. Nucl Instruments Methods Phys Res Sect B Beam Interact with Mater Atoms 361:548-553. https://doi.org/ 10.1016/j.nimb.2015.02.061

Zmuda R, Szewrański S, Kowalczyk T et al (2009) Landscape alteration in view of soil protection from water erosion - an example of the Mielnica watershed. J Water L Dev 13:161-175. https://doi. org/10.2478/v10025-010-0026-5

Zollinger B, Alewell C, Kneisel C et al (2015) The effect of permafrost on time-split soil erosion using radionuclides (137Cs, $239+$ $240 \mathrm{Pu}$, meteoric $10 \mathrm{Be}$ ) and stable isotopes $(\delta 13 \mathrm{C})$ in the eastern Swiss Alps. J Soils Sediments 15:1400-1419. https://doi.org/10. 1007/s11368-014-0881-9

Publisher's Note Springer Nature remains neutral with regard to jurisdictional claims in published maps and institutional affiliations. 